\title{
RESPONDING OF LONG GREEN PEPPER PLANTS TO DIFFERENT SOURCES OF FOLIAR POTASSIUM FERTILISER
}

\author{
MOHAMED M. EL-MOGY*, AZZA M. SALAMA, HANAA F. Y. MOHAMED, \\ KARIMA F. ABDELGAWAD and EMAD A. ABDELDAYM
}

Cairo University, Faculty of Agriculture, Giza, Egypt

\begin{abstract}
EL-MOGY, M.M. - SALAMA, A.M. - MOHAMED, H.F.Y. - ABDELGAWAD, K.F. - ABDELDAYM, E.A.: Responding of long green pepper plants to different sources of foliar potassium fertiliser. Agriculture (Polnohospodárstvo), vol. 65,2019 , no. 2 , pp. $59-76$.
\end{abstract}

The aim of this study was to explore the efficiency of foliar potassium fertiliser relative to morphological, physiological and biochemical properties of hybrid long pepper (Capsicum annuum). Pepper plants were grown in a greenhouse and supplied with three sources of foliar potassium fertilisers, i.e., potassium-humate $(1 \mathrm{~g} / \mathrm{L}=1,250 \mathrm{~g} / \mathrm{ha})$, potassium sulfate $(1 \mathrm{~g} / \mathrm{L}=1,250 \mathrm{~g} / \mathrm{ha})$, and potassium chloride $(1 \mathrm{~g} / \mathrm{L}=1,250 \mathrm{~g} / \mathrm{ha})$. Water served as control. The impacts of these treatments on the phytosynthetic parameters (photosynthetic rate, stomatal conductance, intercellular $\mathrm{CO}_{2}$, leaf carotenoids) and chlorophyll $a$ and $b$, metabolic compounds and nitrogen, phosphorus and potassium were measured. The phytosynthetic parameters significantly improved by different foliar potassium application and the highest level of photosynthetic activity was noted in plants supplied with potassium sulfate, followed by potassium-humate and potassium chloride. Plant biomass accumulation, cholorophyll ( $a$ and $b$ ), and total yield showed larger increases in plants fertilised with potassium sulfate than those fertilised with potassium-humate; smallest increases occurred with potassium chloride. Concentrations of total sugars, carotenoids, chlorophyll ( $a$ and $b$ ), and endogenous level of nitrogen, phosphorus, and potassium contents in plants and fruits were possitively influenced by varying sources of potassium. The fruit color parameters and total soluble solid were also significantly increased with all foliar potassium treatments compared with control. Foliar application of potassium sulfate recorded the highest values and significantly increase all anatomical characters for leaf, stem and fruit of pepper plant.

Key words: Capsicum annum, nutritional value, leaf pigments, anatomy, photosynthetic parameters

Potassium $(\mathrm{K})$ is the most important mineral element for plant growth and development (Bahmanyar \& Mashae 2010). Potassium and other microelements ( $\mathrm{Zn}$ and $\mathrm{Fe}$ ) have an essential role as an enzyme activator for cell's metabolic processes, including respiration, protein synthesis and photosynthesis (Farago 2008; Mahmoud et al. 2019). Also, $\mathrm{K}$ has a significant role in turgor-driven cell growth. Macro or microelements in foliar fertilisers have positive influence on plant growth. $\mathrm{K}$ is known as the "quality element" because of its role in improv- ing the plant quality in general (Lester et al. 2006). The availability of $\mathrm{K}$ during plant growth is often inadequate because of its poor uptake by roots and the competitive absorption inhibition by calcium and magnesium elements. Therefore, foliar K application could be a supplemental way to increase $\mathrm{K}$ element in plant tissues.

Some previous studies have examined the effects of $\mathrm{K}$ fertilisers on pepper yield (Golcz et al. 2012) and pepper fruit quality (Shehata et al. 2018). Reportedly, $\mathrm{K}$ fertiliser had positive effects on growth,

Mohamed M. El-Mogy (*Corresponding author), Karima F. Abdelgawad, Emad A. Abdeldaym, Vegetable Crops Department, Faculty of Agriculture, Cairo University, Giza, Egypt. E-mail: elmogy@agr.cu.edu.eg

Azza M. Salama, Agricultural Botany Department, Faculty of Agriculture, Cairo University, Giza, Egypt

Hanaa F. Y. Mohamed, Plant Physiology Section, Department of Agriculture Botany, Faculty of Agriculture, Cairo University, Giza, Egypt 
yield and quality of the fruit of pepper plant (Botella et al. 2017; Abdelaziz \& Abdeldaym 2018). The available sources of $\mathrm{K}$ used for plant mineral fertiliser are potassium chloride $(\mathrm{KCl})$, potassium sulfate $\left(\mathrm{K}_{2} \mathrm{SO}_{4}\right)$, and potassium nitrate $\left(\mathrm{KNO}_{3}\right)$.

Pepper (Capsicum annuum L.) is considered one of the most popular horticultural crops in North Africa and the Mediterranean because of its economic value and nutritional properties. Pepper fruit is a good source of many nutrients and antioxidants, such as vitamin C (Vit. C) and phenolic compounds. Some previous works indicated that $\mathrm{K}$ fertiliser had a positive effect on fruit size, total soluble solids, ascorbic acid concentration, and fruit surface colour (Lester et al. 2006). There are few studies reporting the sources of $\mathrm{K}$ and its effects on chemical composition, quality, and anatomy of vegetable crops. Therefore, the aim of this study was to determine if supplemental foliar potassium applications during plant growth and fruit development would enhance growth, yield, and fruit quality of pepper. In addition, comparison of different potassium sources supplements on plant growth and fruit quality of pepper.

\section{MATERIAL AND METHODS}

\section{Plant material, growth condition, and treatments}

Experiments were conducted in a plastic greenhouse measuring $40 \times 9$ meters. This study was conducted from the $5^{\text {th }}$ of October 2015 till the end of April 2016 and was repeated from the $10^{\text {th }}$ of October 2016 till the end of April 2017 at the Experimental station in the Faculty of Agriculture of Cairo University, Giza, Egypt (latitude $30.0131^{\circ} \mathrm{N}$, longitude $\left.31.2089^{\circ} \mathrm{E}, 694 \mathrm{~m}\right)$. Seeds of pepper cv. Dolci hybrid were sown on $1^{\text {st }}$ and $5^{\text {th }}$ August 2015 and 2016, respectively, by hand in foam trays ( 209 wells) filled with peat moss and vermiculite $(1: 1, \mathrm{v}: \mathrm{v})$. Developing seedlings were irrigated daily and fertilised with NPK (15:15:15) once weekly. The seedlings were transplanted after 45 days in both seasons. The soil properties of experiment were determined and are summarized in Table 1. The experimental soil was deeply plowed and five flat beds ( $40 \mathrm{~m}$ length $\times 1 \mathrm{~m}$ width) were prepared. Twoweeks before peppertransplanting (45 days), $\mathrm{N}$ (79 kg/ha), $\mathrm{P}_{2} \mathrm{O}_{5}(165.6 \mathrm{~kg} / \mathrm{ha})$ and $\mathrm{K}_{2} \mathrm{O}(60 \mathrm{~kg} / \mathrm{ha})$ were applied as per soil analysis results. A randomized complete block design with four replicates was used. The transplants were arranged in two rows on each ridge. The plot area was $4 \mathrm{~m}^{2}$ ( $4 \mathrm{~m}$ length $\times 1 \mathrm{~m}$ width); the spacing between plants was $0.30 \mathrm{~m}$ and $0.50 \mathrm{~m}$ between rows. Weeds were manually removed shortly after emergence. After 15 days of seedlings transplantation, pepper plants were sprayed, once every 10 days for 5 times, with the following treatments: A) K-humate (65\% humic acid and $15 \%$ potassium) at a rate of $1 \mathrm{~g} / \mathrm{L}$ (equal 1,250 g/ha), B) $\mathrm{K}_{2} \mathrm{SO}_{4}$ (48\% potassium) at a rate of $1 \mathrm{~g} / \mathrm{L}$ (equal 1,250 g/ha), C) $\mathrm{KCl}(52.2 \%$ potassium) at a rate of $1 \mathrm{~g} / \mathrm{L}$ (equal $1,250 \mathrm{~g} / \mathrm{ha}$ ) and D) control was without $\mathrm{K}$ application.

\section{Plant growth parameters}

Ten plants were randomly sampled from each plot after 70 days of transplanting to determine

$\mathrm{T}$ a

Chemical analysis of the soil in 2015-2016 and 2016-2017

\begin{tabular}{|c|c|c|c|c|c|c|}
\hline \multicolumn{5}{|c|}{ Available cations [ppm] } & \multirow{2}{*}{$\begin{array}{c}\text { Soil electrical } \\
\text { conductivity } \\
{[\mathrm{dS} / \mathrm{m}]}\end{array}$} & \multirow{2}{*}{ Soil pH } \\
\hline Year & $\mathrm{K}^{+}[\mathrm{ppm}]$ & $\mathrm{Na}^{+}[\mathrm{ppm}]$ & $\mathrm{Ca}^{++}[\mathrm{ppm}]$ & $\mathrm{Mg}^{++}[\mathrm{ppm}]$ & & \\
\hline $2015-2016$ & 323 & 9.2 & 29 & 17.02 & 0.37 & 7.89 \\
\hline $2016-2017$ & 350 & 10.11 & 35 & 18.48 & 0.44 & 7.56 \\
\hline \multicolumn{7}{|c|}{ Available cations [ppm] } \\
\hline Year & $\mathrm{N}$ & $\mathrm{P}$ & $\mathrm{Zn}$ & $\mathrm{Mn}$ & $\mathrm{Cu}$ & $\mathrm{Fe}$ \\
\hline $2015-2016$ & 32 & 20 & 0.48 & 0.54 & 0.65 & 1.16 \\
\hline $2016-2017$ & 27 & 26 & 0.33 & 0.67 & 0.42 & 1.10 \\
\hline
\end{tabular}


growth traits. Plant height, number of branches and plant fresh and dry weight were recorded.

\section{Photosynthetic parameters}

The fifth leaf of ten plants was selected to assess net photosynthesis $(\mathrm{Pn})$ on an area basis $(\mu \mathrm{mol} \mathrm{CO} /$ $\mathrm{m}^{2} / \mathrm{s}$ ), leaf stomatal conductance to $\mathrm{H}_{2} \mathrm{O}(\mathrm{Gs})$ ( $\mathrm{mol}$ $\mathrm{H}_{2} \mathrm{O} / \mathrm{m}^{2} / \mathrm{s}$ ), and intercellular $\mathrm{CO}_{2}$ concentration $(\mathrm{Ci})$ $(\mu \mathrm{mol} \mathrm{CO} / \mathrm{mol})$ using infra-red gas analyser LICOR 6400 Portable Photosynthesis System (IRGA, Licor Inc., USA).

\section{Leaf chlorophyll $a, b$, and carotenoids content}

Fresh leaves and fruits (90 and 120 days after transplanting, respectively) were extracted with acetone (80\%) (Sigma-Aldrich Co. LLC) and placed for one hour at $5^{\circ} \mathrm{C}$. The extractions were centrifuged for $15 \mathrm{~min}$ at 3,000 $\mathrm{x}$. Chlorophyll $a, b$, and carotenoids content were measured with a spectrophotometer (Helios UVG1702E, England) at wave lengths 663,647 , and $470 \mathrm{~nm}$, respectively. Chlorophyll and carotenoids were measured according to the method of Lichtenthaler and Wellburn (1983). The calculation was done according to the following equations:

$$
\begin{aligned}
& \text { Chlorophyll } a=12.70 \times \mathrm{A}_{663}-2.79 \times \mathrm{A}_{647} \\
& \text { Chlorophyll } b=20 \times \mathrm{A}_{647}-4.62 \times \mathrm{A}_{663} \\
& \text { Carotenoids }=\{1000 \times \mathrm{A} 470-(3.27 \mathrm{chl} . \mathrm{A}-104 \\
& \text { chl. B })\} / 229
\end{aligned}
$$

\section{Total yield}

Total yield were harvested during the season and weighted. The total yield represented in kg per plant.

\section{Colour measurement}

The surface colour of pepper fruits was recorded by measuring, $\mathrm{a}^{*}$ (from red to green), $\mathrm{b}^{*}$ (from yellow to blue), and $C^{*}$ (colour saturation) with a Minolta Chroma Meter (model CR-200, USA). To measure surface colour, three readings were taken from opposite positions of each pepper fruit at mature stage. Ten fruits were analysed for each treatment. The colorimeter was calibrated using a white surface.

\section{Fruit firmness, total soluble solids, and vitamin $C$ content}

Ten fruits at mature stage were used for measuring firmness. Three different fixed positions were used for measuring the firmness on each fruit. Firmness was measured with a fruit pressure tester (FT011, Wagner Instruments, Italy). The results were expressed in Newton $(\mathrm{N})$. The total soluble solids (TSS) in pepper fruit were measured by using a digital refractometer (model PR101, Co. Ltd., Japan). A drop of the juice was placed on the lens and the reading was taken in degrees Brix $\left({ }^{\circ} \mathrm{Bx}\right)$ and expressed as \% soluble solids content in the fruit. Calibration made with distilled water and the lens was carefully rinsed, between samples, with distilled water twice. Fruit samples were randomly taken at harvesting time (mature stage) to determine vitamin $\mathrm{C}$ content in the fruit as $\mathrm{mg} / \mathrm{g}$ fresh weight according to the method described by AOAC (1990).

\section{Macro-elements content in plant and fruits (NPK)}

Total nitrogen $(\mathrm{N})$, phosphorus $(\mathrm{P})$ and potassium $(\mathrm{K})$ concentrations were determined in leaves, stems and fruits. Leaves, stems and fruits were dried at $70^{\circ} \mathrm{C}$ for $48 \mathrm{~h}$ and wet digestion of $0.2 \mathrm{~g}$ fine powder of dry material was carried out with sulphuric and perchloric acids, as described by Piper (1947). Nitrogen was determined with the modified "Micro Kjeldahl" apparatus of Parnas and Wagner as described by Pregl (1945). Phosphorus was determined spectrophotometrically by using stannous chloride method according to (AOAC 1975). Potassium was measured with flame photometer according to the method described by Brown and Lilliland (1964).

\section{Total sugars and total phenols contents}

Ethanol extracts of leaves and fruits were used to determine total sugars and total phenols. For preparation of ethanol extract, $5 \mathrm{~g}$ of fresh peppers were crushed in a porcelain mortar using $25 \mathrm{ml}$ of $95 \%$ ethanol (Sigma-Aldrich, Germany) for $10 \mathrm{~min}$ and then filtrated through a sintered glass funnel $\left(G_{3}\right)$. The residue was re-extracted and filtered twice with ethanol (80\%), and then the volume was adjusted to $25 \mathrm{ml}$ with ethanol (80\%). In the ethanol extract, total sugar was measured via the phosphomolybdic acid method according to AOAC (1975). Total phenol was measured using the Folin-Ciocalteu reagent (Sigma-Aldrich, Germany) according to Swain and Hillis (1959) as follows: ethanolic extract (1 $\mathrm{ml})$ and $1 \mathrm{ml}$ Folin - Denis reagent in a test tube and immediately followed by the addition of $1 \mathrm{ml}$ of $14 \%$ sodium carbonate. Tubes were left for $10 \mathrm{~min}$ at room 
temperature. The absorbance of the developed colour was read at $725 \mathrm{~nm}$ using a spectrophotometer (Hitachi, U-1000). A standard curve was carried out using tryptophan (Sigma-Aldrich, Germany) with a suitable concentration which was treated in the same manner as described above. The concentration of total phenols was calculated and expressed as $\mathrm{mg} / \mathrm{g}$ fresh weight of leaves and fruits of the pepper plant.

\section{Anatomical study}

The samples of leaf and stem were taken throught the $2^{\text {nd }}$ growing season of 2016-2017 from the $4^{\text {th }}$ internode from the top of the main stem at 90 days from sowing. The fruit samples were collected at mature stage (120 days after sowing). The vegetative specimens were fixed in F.A.A. $(10 \mathrm{ml}$ formalin, $5 \mathrm{ml}$ glacial acetic acid, $50 \mathrm{ml}$ ethyl alcohol $95 \%, 35 \mathrm{ml}$ distilled water), washed in $50 \%$ ethyl alcohol, dehydrated in a normal butyl alcohol series, embedded in paraffin wax with a melting point of $60-63^{\circ} \mathrm{C}$, sectioned into $20 \mu \mathrm{m}$ in thickness, stained with the double stain method (crystal violet/erythrosine), cleared in xylene and mounted in Canada balsam (Nassar \& El-Sahhar 1998). The slides were microscopically examined and photomicrographed at Botany Department, Faculty of Agriculture, Cairo University. Measurements $(\mu \mathrm{m})$ were taken using a micrometry piece, with average of readings 3 slides per treatment was calculated.

\section{Statistical analyses}

The experiment was arranged in a completely randomized block design with four replications. Data were exposed to analysis of variance using Mstat-c program (version 2.1). If the interaction was significant it was used to explain the data. If the interaction was not significant, means were separated using least significant difference by Duncan's multiple range test at $P<0.05$. Principal component analysis (PCA) was used to determinate the associations between observed variables and a new set of non-correlated parameters (variables).

\section{RESULTS AND DISCUSSION}

\section{Plant growth and development}

Data in Table 2 shows the effects of year, treat- ment, and year $\times$ treatment interaction on plant growth parameters. Plant fresh weight was affected only by year. Fresh weight of pepper plants was higher in 2016/2017 than in 2015/2016 (Figure 1A). Plant height was affected only by $\mathrm{K}$ treatments. The tallest plants were recorded from plants received $\mathrm{K}_{2} \mathrm{SO}_{4}$ fertiliser followed by $\mathrm{KCl}$, while the control and K-humate were lower and similar (Table 3). Number of branches affected only by K treatments. All sources of $\mathrm{K}$ significantly increased number of branches compared to control plants (Table 3). The highest number of branches values recorded from plants treated with $\mathrm{K}_{2} \mathrm{SO}_{4}$ followed by K-humate and $\mathrm{KCl}$ with no significant difference between them. Dry matter of plants [\%] is affected by year and treatment factors (Table 2). Dry matter in the second season (2016/2017) was higher than first seasons (2015/2016, Figure 1B). All foliar K sources treatments were similar in dry matter and higher than control (Table 3). In this study, plant growth parameters of long pepper, including plant height, number of branches and dry biomass accumulation were positively influenced by foliar $\mathrm{K}$ fertilisers. The difference between years of study on the fresh weight could be due to the variability of micro-climate conditions surrounding the plants. Accumulation of plant dry matter improved significantly with foliar K treatments. Also, there is a positive association between dry matter, net Pn and photosynthetic pigment (chlorophyll $a$ ) (Figure 2B). This indicated that enhancement in dry matter of pepper plants supplied with $\mathrm{K}$ is highly associated to leaf chlorophyll $a$ and photosynthesis rates that increase total sugar accumulation which act as main organic component of the dry matter. Our results in Figure 2B indicated a correlation between leaf $\mathrm{K}$ content, chlorophyll $b$, and plant height. The obtained results were in agreement with previous studies reported that $\mathrm{K}$ fertiliser increased the plant height and dry weight of tomato plants (Afzal et al. 2015; Botella et al. 2017). O'Toole et al. (1980) mentioned that low levels of $\mathrm{K}$ nutrition resulted in a decrease in dry weight of leaves and stems as well as decrease cell size and compaction of cells per unit area and this lead to decreased leaf thickness of bean plants.

\section{Leaf photosynthesis activities}

In this study, foliar $\mathrm{K}$ treatments only have pos- 
itive influence on photosynthesis activity (Table 2). Maximum values of $\mathrm{Pn}, \mathrm{Gs}$, and $\mathrm{Ci}$ were recorded in pepper plants supplied with $\mathrm{K}_{2} \mathrm{SO}_{4}$ followed by $\mathrm{KCl}$ and $\mathrm{K}$-humate treatments (Figure 3A, B, C). The control was recorded the lowest values. Furthermore, positive correlation was found between photosynthetic parameters (Pn, Gs, and Ci) and leaf $\mathrm{K}$ content (Figure $2 \mathrm{~A}$ and $\mathrm{B}$ ). It was also noted that Gs and $\mathrm{Ci}$ have a positive correlation with net photosynthesis (Figure 2A). This result pointed out that the increase in Pn under foliar $\mathrm{K}$ implementation could be attributed to increase in Gs that stimulated with $\mathrm{K}$ (Figure 2B). This improved $\mathrm{Ci}$ inside the leaves (Ibrahim et al. 2011). These changes could be result from the anions accompanied the $\mathrm{K}$ fertilisers, where the high concentration of $\mathrm{Cl}^{-}$anion reduced the leaf chlorophyll concentration which consequently decreased the $\mathrm{Pn}$ as suggested by Acosta-motos et al. (2017). Generally, net photosynthesis rate of pepper plants supplied with foliar $\mathrm{K}$ fertilisers was better than untreated plants (Sun et al. 2011). Where, photosynthesis rate improved by $\mathrm{K}$ fertiliser through regulating stomata opining and allowing gas exchanges with atmosphere which

T a b 1 e 2

Analysis of variance (mean square) of pepper plant growth and yield

\begin{tabular}{|c|c|c|c|c|c|c|c|c|c|}
\hline Source & $\mathrm{df}$ & $\begin{array}{c}\text { Plant fresh } \\
\text { weight } \\
{[\mathrm{kg}]}\end{array}$ & $\begin{array}{c}\text { Plant } \\
\text { height } \\
{[\mathrm{cm}]}\end{array}$ & $\begin{array}{c}\text { Number of } \\
\text { branches }\end{array}$ & $\begin{array}{c}\text { Dry matter } \\
{[\%]}\end{array}$ & $\begin{array}{c}\text { Yield } \\
{[\mathrm{kg} / \text { plant }]}\end{array}$ & Pn & Gs & $\mathrm{Ci}$ \\
\hline Year $(Y)$ & 1 & $0.39^{+}$ & $400.16^{\mathrm{ns}}$ & $0.66^{\mathrm{ns}}$ & $4.11^{+}$ & $0.05^{++}$ & $0.00^{\mathrm{ns}}$ & $0.00^{\text {ns }}$ & $0.02^{\text {ns }}$ \\
\hline Treatment $(\mathrm{T})$ & 3 & $0.23^{\mathrm{ns}}$ & $532.00^{+}$ & $3.38^{+}$ & $17.22^{+++}$ & $0.08^{+++}$ & $53.55^{+++}$ & $916.99^{+++}$ & $9,581^{+++}$ \\
\hline $\mathrm{Y} \times \mathrm{T}$ & 3 & $0.02^{\mathrm{ns}}$ & $10.83^{\mathrm{ns}}$ & $1.00^{\mathrm{ns}}$ & $2.28^{\mathrm{ns}}$ & $0.00^{\mathrm{ns}}$ & $2.13^{\mathrm{ns}}$ & $0.01^{\mathrm{ns}}$ & $0.002^{\mathrm{ns}}$ \\
\hline
\end{tabular}

${ }_{\mathrm{ns}},{ }^{+},{ }^{++},{ }^{+++}$not significant or significant at $P \leq 0.05, P \leq 0.01, P \leq 0.001$, analysis of variance

T a b 1 e 3

Effect of different sources of $\mathrm{K}$ foliar fertiliser on phytochemicals in shoots of pepper plant. Values within each row followed by the same letter are not statistically different according to Duncan test $(P<0.05 \%)$

\begin{tabular}{|c|c|c|c|c|}
\hline Phytochemicals in shoots & Control & K-humate & $\mathrm{K}_{2} \mathrm{SO}_{4}$ & $\mathrm{KCl}$ \\
\hline Plant height $[\mathrm{cm}]$ & $116.66^{\mathrm{c}}$ & $121.45^{\mathrm{c}}$ & $138.23^{\mathrm{a}}$ & $125.67^{b}$ \\
\hline Number of branches & $3.66^{\mathrm{c}}$ & $4.56^{\mathrm{b}}$ & $5.50^{\mathrm{a}}$ & $4.52^{b}$ \\
\hline Dry matter $[\%]$ & $18.79^{\mathrm{b}}$ & $22.28^{\mathrm{a}}$ & $22.71^{\mathrm{a}}$ & $21.88^{\mathrm{a}}$ \\
\hline Total yield $[\mathrm{kg} / \mathrm{plant}]$ & $0.49^{\mathrm{d}}$ & $0.65^{b}$ & $0.78^{\mathrm{a}}$ & $0.60^{\mathrm{c}}$ \\
\hline Leaves chlorophyll $a$ content $[\mathrm{mg} / \mathrm{g}$ fw] & $1.02^{\mathrm{b}}$ & $1.14^{\mathrm{a}}$ & $1.13^{\mathrm{a}}$ & $1.10^{\mathrm{a}}$ \\
\hline Leaves chlorophyll $b$ content $[\mathrm{mg} / \mathrm{g}$ fw] & $1.04^{\mathrm{c}}$ & $1.20^{\mathrm{a}}$ & $1.18^{\mathrm{ab}}$ & $1.14^{\mathrm{bc}}$ \\
\hline Leaf $\mathrm{N}$ content $[\mathrm{mg} / \mathrm{g} \mathrm{dw}]$ & $27.10^{\mathrm{b}}$ & $29.35^{\mathrm{a}}$ & $25.55^{b}$ & $29.45^{\mathrm{a}}$ \\
\hline Leaf $\mathrm{K}$ content $[\mathrm{mg} / \mathrm{g} \mathrm{dw}]$ & $28.21^{\mathrm{c}}$ & $31.12^{\mathrm{ab}}$ & $31.58^{\mathrm{a}}$ & $29.45^{b}$ \\
\hline Stem $\mathrm{N}$ content $[\mathrm{mg} / \mathrm{g} \mathrm{dw}]$ & $13.10^{\mathrm{ab}}$ & $13.82^{\mathrm{a}}$ & $10.00^{\mathrm{c}}$ & $12.60^{\mathrm{b}}$ \\
\hline Stem $\mathrm{P}$ content $[\mathrm{mg} / \mathrm{g} \mathrm{dw}]$ & $9.05^{b}$ & $11.02^{\mathrm{a}}$ & $11.20^{\mathrm{a}}$ & $10.65^{\mathrm{a}}$ \\
\hline Stem $\mathrm{K}$ content $[\mathrm{mg} / \mathrm{g} \mathrm{dw}]$ & $29.81^{\mathrm{c}}$ & $32.28^{\mathrm{ab}}$ & $33.27^{\mathrm{a}}$ & $31.79^{b}$ \\
\hline Leaf total phenols content $[\mathrm{mg} / \mathrm{g}$ fw] & $2.16^{\mathrm{b}}$ & $3.01^{\mathrm{a}}$ & $2.93^{\mathrm{a}}$ & $2.82^{\mathrm{a}}$ \\
\hline Leaf total sugar $[\mathrm{mg} / \mathrm{g}$ fw] & $1.04^{\mathrm{c}}$ & $1.35^{\mathrm{b}}$ & $1.52^{\mathrm{a}}$ & $1.07^{\mathrm{c}}$ \\
\hline
\end{tabular}



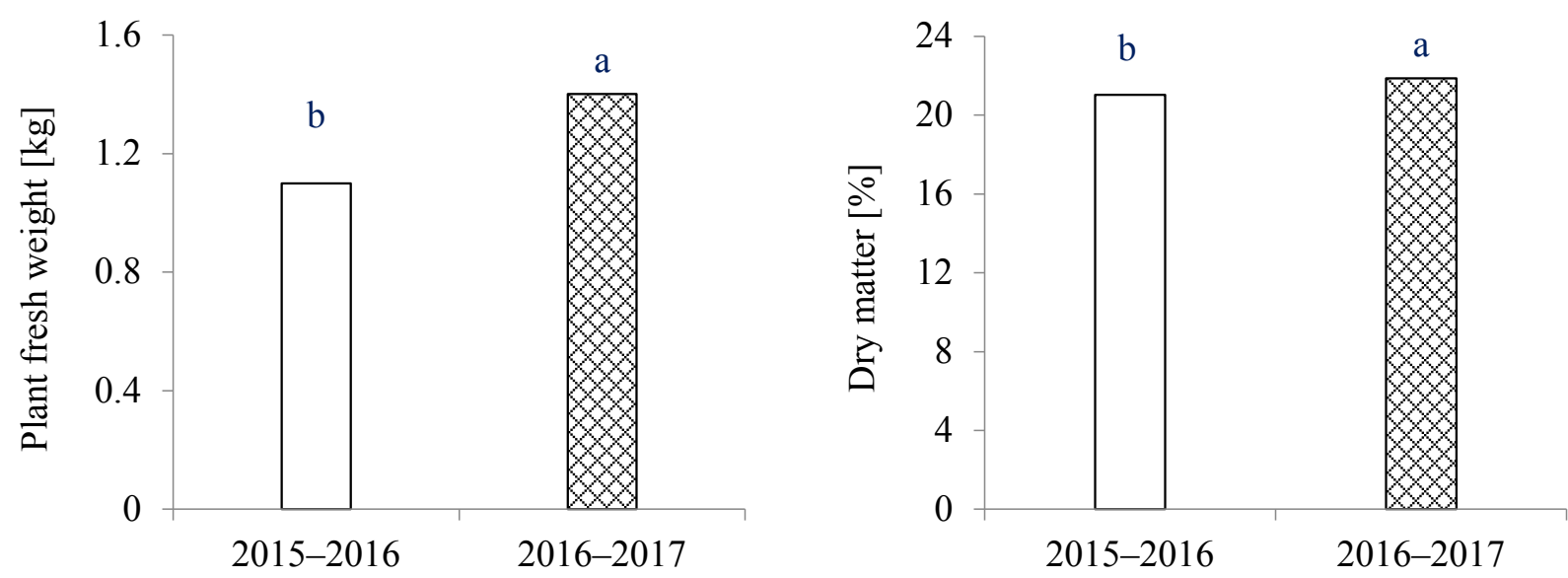

A Year

B Year
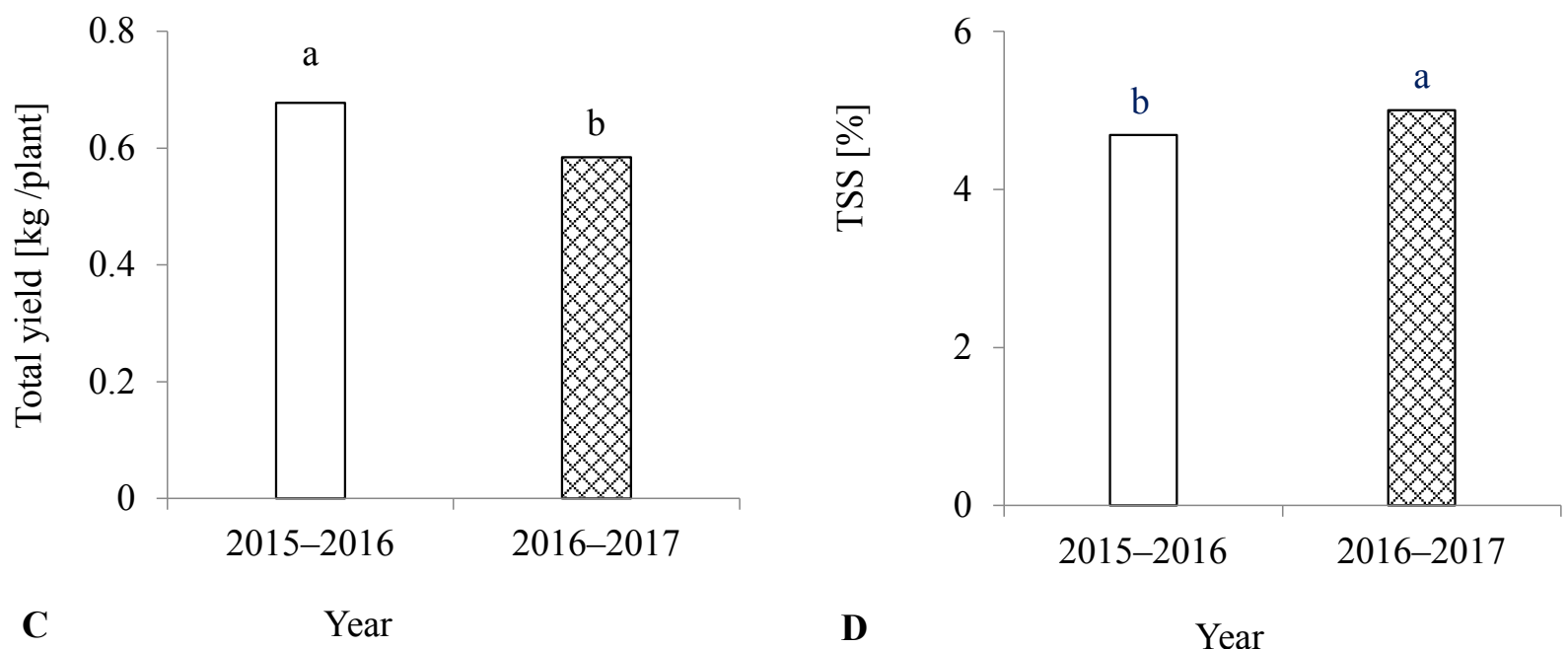

D Year
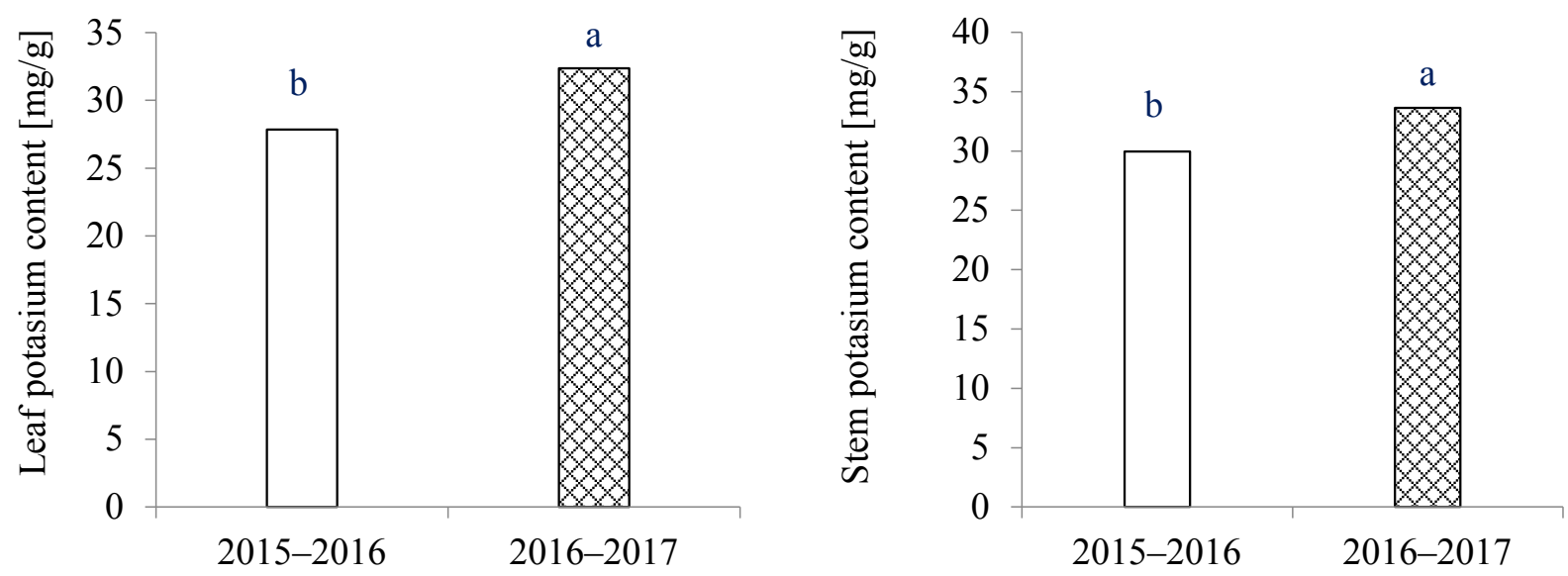

$\mathbf{E}$

Year

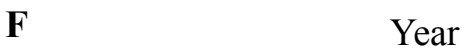

Figure 1. Effect of year on (A) plant fresh weight [kg], (B) dry matter [\%], (C) total yield [kg/plant], (D) TSS [\%], (E) leaf $\mathrm{K}$ content in $[\mathrm{mg} / \mathrm{g} \mathrm{dw}]$ and $(\mathrm{F})$ stem $\mathrm{K}$ content $[\mathrm{mg} / \mathrm{g} \mathrm{dw}]$ 
improves $\mathrm{Ci}$ rate and water use efficiency (Abid et al. 2016; Coskun et al. 2014; Zahoor et al. 2017).

Pigments contents in leaves and fruits (chlorophyll $a, b$ and carotenoids)

Plant pigments, including chlorophyll ( $a$ and $b$ ) and carotenoids are vital molecules that are formed by plants and play an important role in photosynthesis process which is accountable for plant growth (Dobroviczka et al. 2013). Our results indicated that $\mathrm{K}$ treatments affected chlorophyll ( $a$ and $b$ ) in leaves while carotenoids were affected by year $\times$ treatment interaction (Table 4 ). Moreover, all sources of K significantly increased chlorophyll $a$ and $b$ in leaves. The higher values of leaf chlorophyll $b$ content were recorded in plants treated with K-humate and $\mathrm{K}_{2} \mathrm{SO}_{4}$ compared to control (Table 3). The lower chlorophyll $b$ level in pepper leaves was found in plants treated with $\mathrm{KCl}$ compared to other $\mathrm{K}$ treatments. Furthermore, positive correlation between chlorophyll ( $a$ and $b$ ) accumulation in pepper leaves and leaf $\mathrm{K}$ content was observed (Figure 2B). This improvement in chlorophyll ( $a$ and $b$ ) contents due to $\mathrm{K}$ fertiliser could be based on stability of proteins complex and chloroplast structure (Ibrahim et al. 2012). Ghasemzadeh et al. (2010) reported that

T a b 1 e 4

Analysis of variance (mean square) of pepper leaves and fruits chemical compositions

\begin{tabular}{|c|c|c|c|c|c|c|}
\hline Source & $\mathrm{df}$ & $\begin{array}{l}\text { Chlorophyll } a \text { in } \\
\text { leaf }[\mathrm{mg} / \mathrm{g} \mathrm{fw}]\end{array}$ & $\begin{array}{l}\text { Chlorophyll } b \text { in } \\
\text { leaf }[\mathrm{mg} / \mathrm{g} \mathrm{fw}]\end{array}$ & $\begin{array}{c}\text { Carotenoids in leaf } \\
{[\mathrm{mg} / \mathrm{g} \mathrm{fw}]}\end{array}$ & $\begin{array}{l}\text { Chlorophyll } a \text { in } \\
\text { fruits }[\mathrm{mg} / \mathrm{g} \text { fw] }\end{array}$ & $\begin{array}{c}\text { Carotenoids } \\
\text { in fruits } \\
{[\mathrm{mg} / \mathrm{g} \mathrm{fw}]}\end{array}$ \\
\hline Year (Y) & 1 & $0.00^{\mathrm{ns}}$ & $0.02^{\mathrm{ns}}$ & $0.001^{\mathrm{ns}}$ & $0.001^{\mathrm{ns}}$ & $0.002^{\mathrm{ns}}$ \\
\hline Treatment (T) & 3 & $0.02^{+++}$ & $0.03^{++}$ & $0.001^{\mathrm{ns}}$ & $0.002^{+++}$ & $0.002^{+}$ \\
\hline $\mathrm{Y} \times \mathrm{T}$ & 3 & $0.00^{\mathrm{ns}}$ & $0.00^{\mathrm{ns}}$ & $0.002^{++}$ & $0.002^{\mathrm{ns}}$ & $0.002^{\mathrm{ns}}$ \\
\hline
\end{tabular}

$\mathrm{ns},{ }^{+},{ }^{++},{ }^{++}$not significant or significant at $P \leq 0.05, P \leq 0.01, P \leq 0.001$, analysis of variance

$\mathrm{T}$ a b 1 e 5

Effect of different sources of $\mathrm{K}$ foliar fertiliser on phytochemicals in fruits of pepper plant. Values within each row followed by the same letter are not statistically different according to Duncan test $(P<0.05 \%)$

\begin{tabular}{|c|c|c|c|c|}
\hline Parameters & Control & K-humate & $\mathrm{K}_{2} \mathrm{SO}_{4}$ & $\mathrm{KCl}$ \\
\hline Chlorophyll $a[\mathrm{mg} / \mathrm{g} \mathrm{fw}]$ & $0.067^{\mathrm{a}}$ & $0.065^{\mathrm{a}}$ & $0.072^{\mathrm{a}}$ & $0.045^{b}$ \\
\hline Caroteniods [mg/g fw] & $0.028^{c}$ & $0.030^{\mathrm{b}}$ & $0.038^{\mathrm{a}}$ & $0.028^{b}$ \\
\hline$c^{*}$ & $43.08^{c}$ & $48.45^{\mathrm{a}}$ & $46.69^{b}$ & $48.20^{\mathrm{a}}$ \\
\hline$a^{*}$ & $-18.70^{\mathrm{b}}$ & $-19.96^{\mathrm{a}}$ & $-20.70^{\mathrm{a}}$ & $-20.10^{\mathrm{a}}$ \\
\hline$b^{*}$ & $39.67^{\mathrm{d}}$ & $47.06^{\mathrm{a}}$ & $43.92^{\mathrm{b}}$ & $41.60^{c}$ \\
\hline TSS ( ${ }^{\circ}$ Brix) & $4.40^{\mathrm{b}}$ & $4.70^{\mathrm{ab}}$ & $5.20^{\mathrm{a}}$ & $4.90^{\mathrm{a}}$ \\
\hline Vitamin C $[\mathrm{mg} / 100 \mathrm{~g} \mathrm{fw}]$ & $153.70^{d}$ & $156.70^{\mathrm{c}}$ & $176.50^{\mathrm{a}}$ & $167.30^{\mathrm{b}}$ \\
\hline $\mathrm{N}$ content $[\mathrm{mg} / \mathrm{g} \mathrm{dw}]$ & $20.70^{\mathrm{b}}$ & $23.90^{\mathrm{a}}$ & $19.80^{\mathrm{b}}$ & $21.20^{\mathrm{b}}$ \\
\hline$P$ content $[\mathrm{mg} / \mathrm{g} \mathrm{dw}]$ & $6.40^{\mathrm{b}}$ & $7.40^{\mathrm{a}}$ & $6.50^{\mathrm{b}}$ & $6.80^{\mathrm{ab}}$ \\
\hline $\mathrm{K}$ content $[\mathrm{mg} / \mathrm{g} \mathrm{dw}]$ & $20.00^{\mathrm{b}}$ & $23.10^{\mathrm{a}}$ & $23.90^{\mathrm{a}}$ & $23.00^{\mathrm{a}}$ \\
\hline Total Phenols content $[\mathrm{mg} / \mathrm{g} \mathrm{fw}]$ & $1.08^{c}$ & $1.43^{\mathrm{a}}$ & $0.79^{\mathrm{d}}$ & $1.25^{\mathrm{b}}$ \\
\hline Total sugar $[\mathrm{mg} / \mathrm{g} \mathrm{fw}]$ & $1.28^{\mathrm{c}}$ & $2.60^{\mathrm{a}}$ & $2.41^{\mathrm{a}}$ & $1.76^{\mathrm{b}}$ \\
\hline
\end{tabular}


leaf chlorophyll content was increased due to $\mathrm{K}$ fertiliser. Potassium activated chlorophyll synthesis such as porphobilinogenase, ALA dehydratase and $\delta$-aminolevulinic acid (ALA) and avoiding decomposition of newly chlorophyll synthesized. On contrary, the lowest values of chlorophyll $a$ in pepper fruits were recorded in plants treated with $\mathrm{KCl}$ (Table 5). No significant differences were observed among treatments regarding chlorophyll $b$. The reduction of chlorophyll $b$ in leaves and chlorophyll $a$ in pepper fruit caused by $\mathrm{KCl}$ fertiliser was possibly due to adverse effects of accumulated chloride $\left(\mathrm{Cl}^{-}\right)$ ion on chloroplast structure and chlorophyll formation (Salama et al. 1994). The highest level of carotenoids was noted in leaves and fruits of pepper plants supplied with $\mathrm{KCl}$ treatment than other treatments (Figure 4A and Table 5). This improvement possibly induced due to high salinity of $\mathrm{KCl}$ solution than salinity of $\mathrm{K}_{2} \mathrm{SO}_{4}$ and $\mathrm{K}$-humate solution (Kamburova \& Kirilov 2008) which caused more stressful conditions additionally toxicity resulted of $\mathrm{Cl}^{-}$anion accumulation. Whereas, carotenoids is considered

$\mathrm{T}$ a $\mathrm{b} 1$ e 6

Analysis of variance (mean square) of pepper fruits color and chemical compositions

\begin{tabular}{|l|c|c|c|c|c|c|c|}
\hline \multicolumn{1}{|c|}{ Source } & df & $c^{*}$ & $a^{*}$ & $b^{*}$ & TSS [\%] & $\begin{array}{c}\text { Firmness } \\
(\mathrm{N})\end{array}$ & Vit. C \\
\hline Year (Y) & 1 & $0.22^{\text {ns }}$ & $4.40^{\text {ns }}$ & $3.00^{\text {ns }}$ & $0.54^{++}$ & $0.00^{\text {ns }}$ & $0.58^{\text {ns }}$ \\
Treatment (T) & 3 & $29.48^{+}$ & $4.42^{+}$ & $60.71^{+++}$ & $0.61^{+++}$ & $0.77^{\text {ns }}$ & $649.21^{+++}$ \\
Y $\times \mathrm{T}$ & 3 & $1.74^{\text {ns }}$ & $0.17^{\text {ns }}$ & $2.28^{\text {ns }}$ & $0.09^{\text {ns }}$ & $1.44^{+}$ & $0.11^{\text {ns }}$ \\
\hline
\end{tabular}

$\mathrm{ns},{ }^{+},{ }^{++},{ }^{+++}$not significant or significant at $P \leq 0.05, P \leq 0.01, P \leq 0.001$, analysis of variance

T a b 1 e 7

Analysis of variance (mean square) of pepper plant chemical compositions [mg/g dw]

\begin{tabular}{|l|c|c|c|c|c|c|c|}
\hline \multicolumn{1}{|c|}{ Source } & Df & $\begin{array}{c}\text { N content in } \\
\text { leaf }\end{array}$ & $\begin{array}{c}\text { P content in } \\
\text { leaf }\end{array}$ & $\begin{array}{c}\text { K content in } \\
\text { leave }\end{array}$ & $\begin{array}{c}\text { N content in } \\
\text { stem }\end{array}$ & $\begin{array}{c}\text { P content in } \\
\text { stem }\end{array}$ & $\begin{array}{c}\text { K content in } \\
\text { stem }\end{array}$ \\
\hline Year (Y) & 1 & $0.38^{\mathrm{ns}}$ & $0.05^{++}$ & $121.50^{+++}$ & $2.34^{\mathrm{ns}}$ & $0.03^{\mathrm{ns}}$ & $80.66^{++}$ \\
Treatment (T) & 3 & $21.32^{++}$ & $1.12^{+++}$ & $14.48^{++}$ & $16.87^{++}$ & $1.45^{+++}$ \\
$\mathrm{Y} \times \mathrm{T}$ & 3 & $1.65^{\mathrm{ns}}$ & $0.02^{++}$ & $4.94^{\mathrm{ns}}$ & $1.92^{\mathrm{ns}}$ & $0.10^{\mathrm{ns}}$ & $2.33^{\mathrm{ns}}$ \\
\hline
\end{tabular}

ns, ${ }^{+},{ }^{++},{ }^{++}$not significant or significant at $P \leq 0.05, P \leq 0.01, P \leq 0.001$, analysis of variance

T a b 1 e 8

Analysis of variance (mean square) of pepper fruits and leaves chemical compositions

\begin{tabular}{|c|c|c|c|c|c|c|c|c|}
\hline Source & $\mathrm{df}$ & $\begin{array}{l}\mathrm{N} \text { content } \\
\text { in fruits } \\
{[\mathrm{mg} / \mathrm{g} \mathrm{dw}]}\end{array}$ & $\begin{array}{l}\text { P content } \\
\text { in fruits } \\
{[\mathrm{mg} / \mathrm{g} \mathrm{dw}]}\end{array}$ & $\begin{array}{l}\mathrm{K} \text { content } \\
\text { in fruits } \\
{[\mathrm{mg} / \mathrm{g} \mathrm{dw}]}\end{array}$ & $\begin{array}{c}\text { Phenolic } \\
\text { compounds } \\
\text { in leaf } \\
{[\mathrm{mg} / \mathrm{g} \mathrm{fw}]}\end{array}$ & $\begin{array}{c}\text { Phenolic } \\
\text { compounds } \\
\text { in fruits } \\
{[\mathrm{mg} / \mathrm{g} \mathrm{fw}]}\end{array}$ & $\begin{array}{l}\text { Total sugar } \\
\text { in leaf } \\
{[\mathrm{mg} / \mathrm{g} \mathrm{fw}]}\end{array}$ & $\begin{array}{l}\text { Total sugar } \\
\text { in fruits } \\
{[\mathrm{mg} / \mathrm{g} \text { fw }]}\end{array}$ \\
\hline Year (Y) & 1 & $3.60^{\mathrm{ns}}$ & $0.66^{\mathrm{ns}}$ & $1.52^{\mathrm{ns}}$ & $0.06^{\mathrm{ns}}$ & $0.01^{\mathrm{ns}}$ & $0.00^{\mathrm{v}}$ & $0.03^{\mathrm{ns}}$ \\
\hline Treatment (T) & 3 & $18.59^{++}$ & $1.42^{+}$ & $17.15^{+++}$ & $0.52^{+++}$ & $0.45^{+++}$ & $0.32^{+++}$ & $2.23^{+++}$ \\
\hline $\mathrm{Y} \times \mathrm{T}$ & 3 & $10.25^{\mathrm{ns}}$ & $0.05^{\text {ns }}$ & $0.25^{\mathrm{ns}}$ & $0.09^{\text {ns }}$ & $0.03^{\mathrm{ns}}$ & $0.00^{\mathrm{ns}}$ & $0.05^{\mathrm{ns}}$ \\
\hline
\end{tabular}

${ }^{\mathrm{ns}},{ }^{+},{ }^{++},{ }^{++}$not significant or significant at $P \leq 0.05, P \leq 0.01, P \leq 0.001$, analysis of variance 
one of the most important antioxidant compounds which protects the plant cell against oxidative stress resulted of salinity condition (Giuffrida et al. 2014).

\section{Pepper yield}

Analysis of variance showed that year $(P \leq 0.01)$ and $\mathrm{K}$ treatments $(P \leq 0.001)$ significantly influenced total yield (Table 2). The total yield of pepper plant was higher in first year $(2015 / 2016)$ than second year (2016/2017) (Figure 1C). This result might be associated to climate condition generalized during the two seasons. Different sources of K significantly increased total yield per plant compared to control (Table 3). The highest yield was recorded from plants treated with $\mathrm{K}_{2} \mathrm{SO}_{4}$ followed by K-humate and $\mathrm{KCl}$, respectively. Similar results were obtained in other vegetable crops such as pepper and melon (Golcz et al. 2012; Lester et al. 2010). Inthichack et al. (2012) stated that higher yield of celery was obtained by using $\mathrm{K}$ fertiliser in the form of $\mathrm{KCl}$ whereas; the highest yield of cabbage and lettuce resulted from $\mathrm{K}$ fertiliser form the source of $\mathrm{K}_{2} \mathrm{SO}_{4}$. The improvement of fruit yield of pepper plant is strongly correlated with leaf sugar content and $\mathrm{Pn}$ as shown in principle component analysis (Figure 2A). This confirms the statement that increased fruits yield of plants supplied with $\mathrm{K}$ is associated to photosynthetic assimilations (i.e. sugars) and transloca- tion of those assimilates towards sink tissues (Zhao et al. 2001). Chapagain and Wiesman (2004) also observed that tomato fruit biomasses were increased by foliar K application.

\section{Fruits colour}

Our results confirmed that $\mathrm{K}$ fertilisers significantly affected the chroma $\left(\mathrm{C}^{*}\right)$ and $\mathrm{a}^{*}$ (red to green colour) and $\mathrm{b}^{*}$ (yellow to blue colour) values in fruit pepper skin (Table 6). The distinguish colour for normal fruits is yellowish green colour. Data in Table 5 shows that values of a* (green colour) and $b^{*}$ (yellow) were improved by $\mathrm{K}$ fertiliser. Similarly, $\mathrm{C}^{*}$ saturation index was also enhanced. The highest value of $\mathrm{C}^{*}$ was recorded by $\mathrm{K}$-humate and $\mathrm{KCl}$. The value of $\mathrm{a}^{*}$ increased in all $\mathrm{K}$ treatment compared to control, while the highest a* value was recorded by K-humate. The enhancement of colour formation by $\mathrm{K}$ fertiliser could be due to the role of $\mathrm{K}$ element in activation of 60 different enzymes, reduce tissue wilting, and formation of sugars and starch (Fageria 2009).

\section{Fruit firmness, total soluble solid and vitamin $C$ content}

Firmness was affected only by year $\times$ treatments interaction (Figure 4B) but the fruit firmness showed similar trends with control. The highest value of
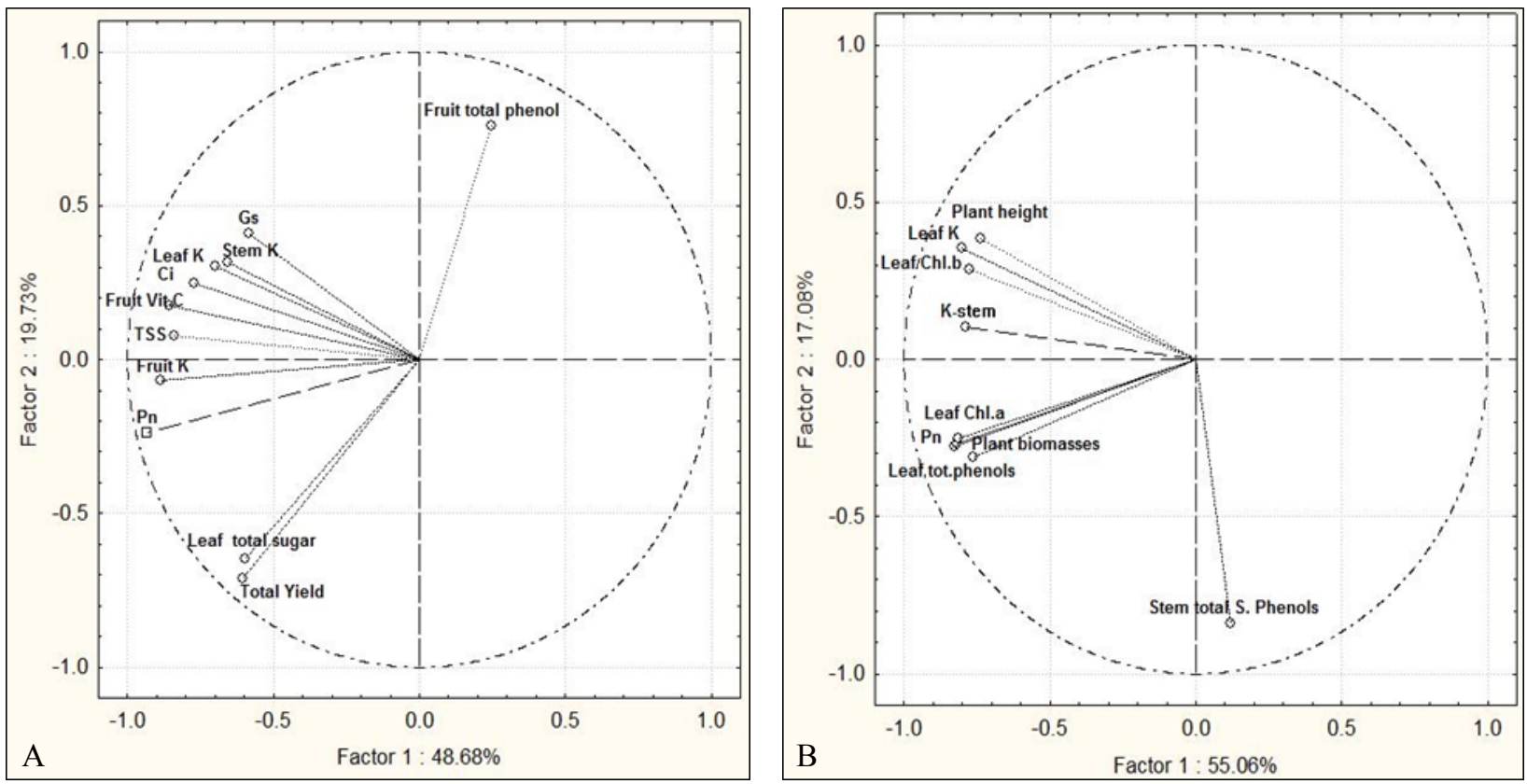

Figure 2. Principal component analysis (PCA) of leaf potassium concentration with different parameters analysed in leaves and fruit of pepper plant 
fruit total soluble solid (TSS) was in second season than first season (Figure 1D). Table 5 indicates that TSS in fruits significantly improved with $\mathrm{K}$ treatment compared to control as similar findings were obtained by Lester et al. (2006). The fruit firmness did not changed with $\mathrm{K}$ fertiliser because the foliar applied $\mathrm{K}$ is not associated to increase membrane integrity or cell wall stability as calcium does (Lester \& Grusak 1999). On the other hand, enhancement of fruit TSS is positively correlated to fruit total sugar $(r=0.82)$, Vit. C $(r=0.72)$ and accumulation of other organic osmolytes as well as $\mathrm{K}(r=0.68)$ in cells of fruit pepper fruit (Figure 2A). Analysis of variance showed that vit. $\mathrm{C}$ accumulation in pepper significantly affected by $\mathrm{K}$ fertiliser (Table 6). Content of Vit. C in pepper fruits treated with K-humate, $\mathrm{K}_{2} \mathrm{SO}_{4}$ and $\mathrm{KCl}$ were increased by $4.9,15.2$ and $10.5 \%$ compared to control (Table 5). Furthermore, fruit Vit. C is correlated positively with Pn, $\mathrm{Ci}$ and leaf $\mathrm{K}$ content (Figure 2A). This implies that $\mathrm{K}$ sources improve $\mathrm{Pn}, \mathrm{Ci}$, and carbohydrate accumulation, assimilates translocation and enzyme activation (Ghasemzadeh et al. 2010; Ghasemzadeh \& Haafar 2011). High concentration of vit. C in pepper fruits supplied with $\mathrm{K}$ probably due to development of total carbohydrate (Norhaiza et al. 2009). This is because D-glucose is considered a precursor for vit. $\mathrm{C}$ biosynthesis in plants, as more availability of carbohydrate lead to vitamin $\mathrm{C}$ might be formed in the L-galactose pathways (Hancock \& Viola 2005).

Macro-element content in plant and fruits (N, P, and K)

Nitrogen content in leaves was affected only by $\mathrm{K}$ treatments (Table 7). The highest contents of $\mathrm{N}$ in

T a b 1 e 9

Effect of different sources of $\mathrm{K}$ foliar fertiliser on histological features of pepper plant leaf

\begin{tabular}{|l|c|c|c|c|}
\hline \multirow{2}{*}{ Characters $[\mu \mathrm{m}]$} & \multicolumn{4}{|c|}{ Treatments } \\
\cline { 2 - 5 } & Control & K-humate & $\mathrm{K}_{2} \mathrm{SO}_{4}$ & $\mathrm{KCl}$ \\
\hline Mid vein thick & $805^{\mathrm{d}}$ & $830^{\mathrm{b}}$ & $885.0^{\mathrm{a}}$ & $819^{\mathrm{c}}$ \\
Lamina thick & $240^{\mathrm{d}}$ & $333^{\mathrm{b}}$ & $341.0^{\mathrm{a}}$ & $265^{\mathrm{c}}$ \\
Palisade tissue thick & $85^{\mathrm{b}}$ & $95^{\mathrm{a}}$ & $97.5^{\mathrm{a}}$ & $93^{\mathrm{a}}$ \\
Spongy tissue thick & $133^{\mathrm{c}}$ & $235^{\mathrm{a}}$ & $241.5^{\mathrm{a}}$ & $145^{\mathrm{b}}$ \\
Dimensions of the main Vascular bundle of mid vein & & & & \\
$\quad \quad$ Length & $120^{\mathrm{d}}$ & $185^{\mathrm{b}}$ & $200^{\mathrm{a}}$ & $128^{\mathrm{c}}$ \\
$\quad$ Width & $420^{\mathrm{d}}$ & $555^{\mathrm{b}}$ & $605^{\mathrm{a}}$ & $430^{\mathrm{c}}$ \\
\hline
\end{tabular}

$\mathrm{T}$ a b 1 e 10

Effect of different sources of $\mathrm{K}$ foliar fertiliser on histological features of pepper plant stem

\begin{tabular}{|l|c|c|c|c|}
\hline \multirow{2}{*}{ Characters $[\mu \mathrm{m}]$} & \multicolumn{4}{|c|}{ Treatments } \\
\cline { 2 - 5 } & Control & K-humate & $\mathrm{K}_{2} \mathrm{SO}_{4}$ & $\mathrm{KCl}$ \\
\hline Main stem diameter & $2,365^{\mathrm{c}}$ & $2,520^{\mathrm{b}}$ & $2,610^{\mathrm{a}}$ & $2,508^{\mathrm{b}}$ \\
Collenchymas thick & $105^{\mathrm{c}}$ & $129^{\mathrm{b}}$ & $150^{\mathrm{a}}$ & $125^{\mathrm{b}}$ \\
Parenchyma thick & $143^{\mathrm{d}}$ & $180^{\mathrm{b}}$ & $210^{\mathrm{a}}$ & $160^{\mathrm{c}}$ \\
Upper phloem tissue thick & $57^{\mathrm{d}}$ & $95^{\mathrm{b}}$ & $110^{\mathrm{a}}$ & $75^{\mathrm{c}}$ \\
Xylem tissue thick & $225^{\mathrm{d}}$ & $315^{\mathrm{b}}$ & $355^{\mathrm{a}}$ & $283^{\mathrm{c}}$ \\
Lower phloem tissue thick & $70^{\mathrm{d}}$ & $90^{\mathrm{b}}$ & $105^{\mathrm{a}}$ & $80^{\mathrm{c}}$ \\
\hline
\end{tabular}


leaves were observed in $\mathrm{K}$-humate and $\mathrm{KCl}$ treatments compared to control and $\mathrm{K}_{2} \mathrm{SO}_{4}$ treatments (Table 3). Also, P content in leaves was affected by year, treatments, and year $\times$ treatments interaction (Table 7). The highest $\mathrm{P}$ content was observed in plants treated with K-humate in both years (Figure 4C). Additionally, $\mathrm{K}$ content in leaves was affected by year and treatments (Table 7). K content in leaves and stems was higher in 2016/2017 than in 2015/2016 (Figure 1E and F). All K treatments increased $\mathrm{K}$ content in leaves compared to control plants (Table 3 ). In case of fruits, the treatment only affected the macro-element content (Table 8). Table 5 shows that the maximum value of total $\mathrm{N}$ and $\mathrm{P}$ were recorded in plants treated with $\mathrm{K}$ humate with insignificant differences between other treatments $\left(\mathrm{K}_{2} \mathrm{SO}_{4}, \mathrm{KCl}\right.$ and Control). On the other hand, vary- ing sources of $\mathrm{K}$ treatments significantly increased endogenous $\mathrm{K}$ fruit content if compared to control. Our investigation confirmed that foliar K supplementation caused also significant changes in nutrient content in plant tissues (Marschner \& Marschner 2012). Nitrogen content in both leaves and fruit tissues of pepper was significantly improved with foliar $\mathrm{K}$ fertilisers in forms $\mathrm{KCl}$ and $\mathrm{K}$-humate $(P \leq 0.05)$ except the form of $\mathrm{K}_{2} \mathrm{SO}_{4}$. These results were in agreement with Golcz et al. (2004), who found that $\mathrm{K}_{2} \mathrm{SO}_{4}$ reduced total $\mathrm{N}$ in both leaves and fruit of hot pepper than $\mathrm{KCl}$. Previous works confirmed our findings concerning accumulation of $\mathrm{K}$ and $\mathrm{N}$ in plant organs were significantly increased due to $\mathrm{K}$ exposure (Lester et al. 2005). Pervez et al. (2006) also reported that sufficient rates of $\mathrm{K}$ are required for conserving $\mathrm{N}$ metabolism. The increasing of $\mathrm{K}$
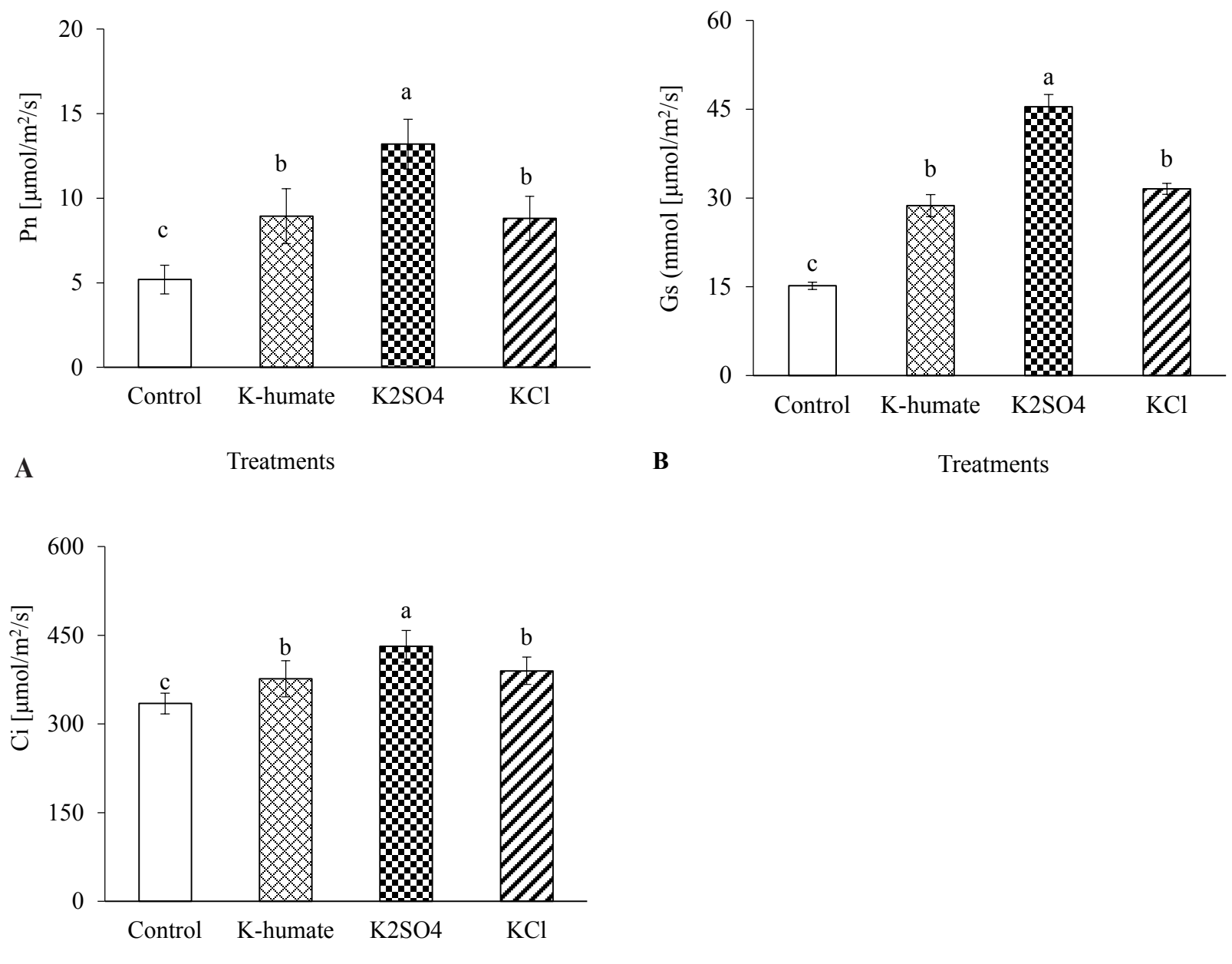

C

Treatments

Figure 3. Effect of different sources of $\mathrm{K}$ foliar fertiliser on (A) Net photosynthetic rate (Pn), (B) Stomatal conductance (Gs), and (C) Intercellular $\mathrm{CO}_{2}(\mathrm{Ci})$, Colum with same letter (s) are not significantly different according to Duncan test $(P \leq 0.05)$. 
concentration in pepper leaves and fruits could be explained by the capability of plant to absorb extra $\mathrm{K}$ even adequate soil $\mathrm{K}$ fertiliser was added. The similar trend of $\mathrm{P}$ was observed in pepper plants treated by foliar $\mathrm{K}$ fertiliser. Adequate amount of $\mathrm{K}$ is needed for absorption $\mathrm{P}$ as well as positive $\mathrm{P}-\mathrm{K}$ interaction in improving crop yield and had been observed by Pervez et al. (2006). Besides, improvement of $\mathrm{P}$ and $\mathrm{N}$ values in pepper fruits treated with $\mathrm{K}$-humate might be returned to composition of product where it has extra elements as $\mathrm{P}$ and $\mathrm{N}$ (Tripura et al. 2017).

\section{Fruit total sugars content}

Data in Table 8 indicated that total sugar in leaves and fruits were affected only by $\mathrm{K}$ treatments. Total sugar in pepper leaves due to treatment with $\mathrm{K}_{2} \mathrm{SO}_{4}$ and $\mathrm{K}$-humate was significantly higher than control and $\mathrm{KCl}$ treatments (Table 3). Total sugar contents in fruit of pepper plants treated with different $\mathrm{K}$ sources were higher than control plants (Table 5). Foliar K-humate, $\mathrm{K}_{2} \mathrm{SO}_{4}$ and $\mathrm{KCl}$ fertiliser increased total sugar contents by $23,27.6$ and $2.9 \%$ in leaf and $50.76,48.88$ and $27.30 \%$ in fruits, respectively (Tables 3 and 5). Leaf total sugar concentration is correlated positively with photosynthesis rate (Figure $2 \mathrm{~A}$ and $\mathrm{B}$ ). These results confirmed that increasing net photosynthesis rates led to increasing total sugars biosynthesis and tented to accumulate. Similarly, Lester et al. (2010) found that trend of sucrose, glucose and fructose in melon were improved with foliar K fertiliser. Higher total sugar content can be explained by role of $\mathrm{K}$ as cofactor in activation of enzymes involved to biosynthesis and hydrolysis of carbohydrates, translocation of their diverters from leaves to fruits and neutralization of important organic acids. A significant reduction in total sugars in leaves and fruits of pepper plants exposed to $\mathrm{KCl}$ fertiliser could be explained by the harmful effect of chloride salt stress which might be decreased chlorophyll concentration, reduced photosynthesis activity, disturbed source-sink and sucrose synthase (Lin et al. 2004; Peng et al. 2016).

\section{Total phenols content}

Analysis of variance showed that total phenols in leaves was affected by treatment and in fruits affected by treatments and year $\times$ treatments interaction (Table 8 and Figure 4D). In general, total phenols were increased in the leaves of pepper plants supplied with foliar $\mathrm{K}$ fertilisers. The production of total phenols increased with $\mathrm{K}_{2} \mathrm{SO}_{4}$, K-humate and $\mathrm{KCl}$ supplementation by $26.27,28.23$ and $23.4 \%$ in leaves (Table 3). In pepper fruits, the highest total phenols were recorded in K-humate treatment followed by $\mathrm{KCl}$ treatment and then the control. Moreover, $\mathrm{K}_{2} \mathrm{SO}_{4}$ treatment had the lowest value (Table 5). Our results confirmed the earlier studies relating to the influence of $\mathrm{K}$ on total phenols accumulation in plant leaves (Ibrahim et al. 2012). The increase of total phenols level with foliar $\mathrm{K}$ fertiliser in this study could be due to enhancement of total sugar content and photosynthesis as suggested by Ibrahim et al. (2011). This might be due to $\mathrm{K}$ which plays a vital role in stimulating photosynthesis activity and improving the translocation of sugars into dif-

$\mathrm{T}$ a b 1 e 11

Effect of different sources of $\mathrm{K}$ foliar fertiliser on histological features of pepper plant fruit

\begin{tabular}{|c|c|c|c|c|}
\hline \multirow{2}{*}{ Characters $[\mu \mathrm{m}]$} & \multicolumn{3}{|c|}{ Treatments } & \multirow[b]{2}{*}{$\mathrm{KCl}$} \\
\hline & Control & K-humate & $\mathrm{K}_{2} \mathrm{SO}_{4}$ & \\
\hline Outer epidermis (exocarp) thick & $18^{\mathrm{b}}$ & $23^{\mathrm{a}}$ & $25^{\mathrm{a}}$ & $22^{\mathrm{a}}$ \\
\hline Collenchyma thick & $55^{\mathrm{d}}$ & $71^{\mathrm{b}}$ & $95^{\mathrm{a}}$ & $65^{\mathrm{c}}$ \\
\hline Parenchyma thick & $710^{c}$ & $877^{\mathrm{a}}$ & $885^{\mathrm{a}}$ & $815^{\mathrm{b}}$ \\
\hline Vascular bundle diameter & $90^{\mathrm{b}}$ & $111^{\mathrm{a}}$ & $115^{\mathrm{a}}$ & $100^{\mathrm{a}}$ \\
\hline Inner epidermis (endocarp) thick & $28^{\mathrm{b}}$ & $38^{\mathrm{a}}$ & $40^{\mathrm{a}}$ & $35^{\mathrm{a}}$ \\
\hline Whole pericarp thick & $1,109^{\mathrm{d}}$ & $1,265^{\mathrm{b}}$ & $1,430^{\mathrm{a}}$ & $1,160^{\mathrm{c}}$ \\
\hline
\end{tabular}


ferent part of plant. This increment in translocation indirectly improved the biosynthesis of total phenols of pepper supplied with foliar $\mathrm{K}$ fertiliser. From PCA (Figure 2) it was shown a positive relationship between Pn and total phenols in leaves of pepper plants (Figure 2B). Carbohydrates are necessary to phenolic substances biosynthesis through the shikimic acid pathway where more carbohydrates derived from glycolysis and the pentose phosphate pathway are transformed into aromatic amino acids (Shui et al. 2009). Other studies suggested that total phenols in pepper is positively correlated to high phenylalanine ammonia-lyase (PAL) activity, where, this enzyme uses $\mathrm{K}$ as cofactor to synthesis phenolic compounds (Ibrahim et al. 2012). The high activity of this enzyme (PAL) was also noted in maize (Li et al. 2009) when plants exposed to high $\mathrm{K}$ rates.

\section{Anatomical studies}

Anatomical study proven that foliar $\mathrm{K}$ fertiliser improved the cell size and thickness of different tissues of pepper leaf and stem. Plants treated with foliar $\mathrm{K}$ in form $\mathrm{K}_{2} \mathrm{SO}_{4}$ recorded the highest values and improved different tissues thickness of pepper leaf and stem than other $\mathrm{K}$ treatments ( $\mathrm{KCl}, \mathrm{K}$-humate). Foliar application with $\mathrm{K}_{2} \mathrm{SO}_{4}$ showed an increase in thickness of mid vein, lamina, palisade and spongy tissues of leaves by $9.9,42.0,14.7$ and $81.6 \%$, respectively in comparison to control. The main vas-
ㅁ2015-2016 圈2016-2017

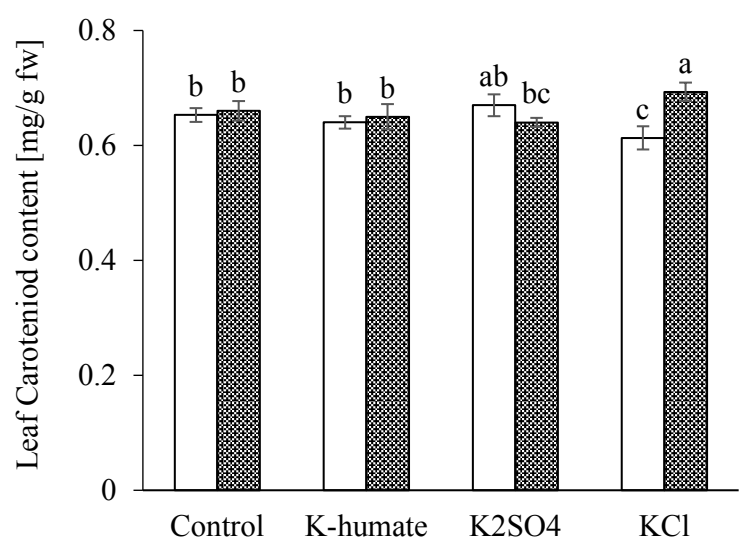

A

Treatments

ㅁ2015-2016 图2016-2017

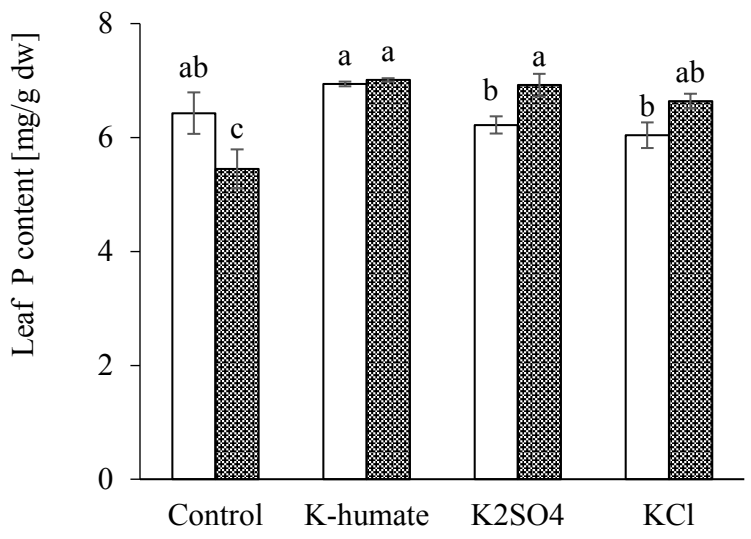

C

Treatments

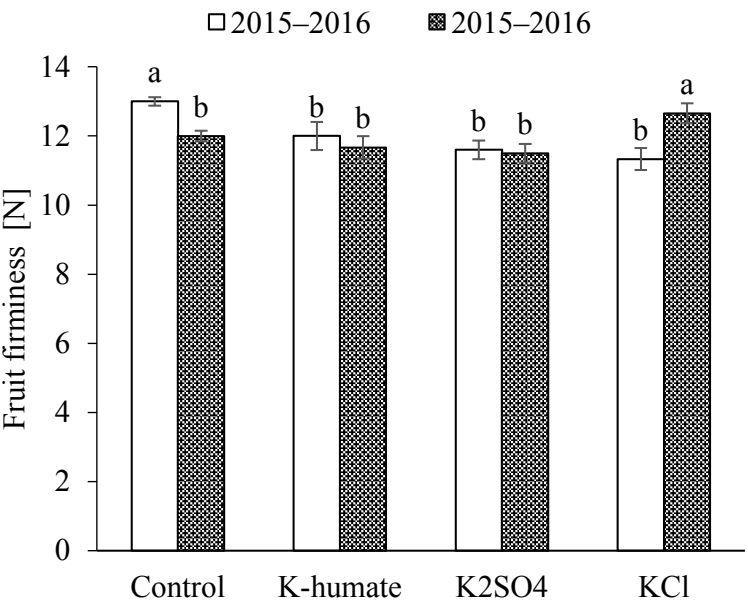

B

Treatments

2015-2016 图2016-2017

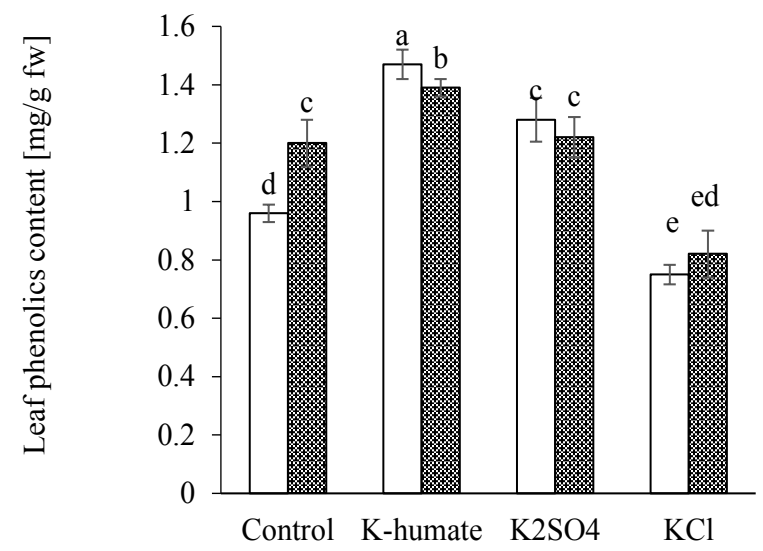

D

Treatments

Figure 4. Effect of Year $\times$ Treatment interaction on (A) Leaf carotenoids content $[\mathrm{mg} / \mathrm{g} \mathrm{fw}]$, (B) Fruit firmness (N), (C) Leaf $\mathrm{P}$ content $[\mathrm{mg} / \mathrm{g} \mathrm{dw}]$ and (D) Leaf phenolics content $[\mathrm{mg} / \mathrm{g} \mathrm{fw}]$ 
cular bundle of mid vein increased in length and width by 66.6 and $44.0 \%$, respectively compared to control (Table 9 and Figure 5). Also, plants treated with $\mathrm{K}_{2} \mathrm{SO}_{4}$ showed an increase in stem diameter, collenchymas and parenchyma thickness, upper and lower phloem and xylem tissues of pepper plant stem by $10.3,42.8,46.8,92.9,50.0$ and $57.7 \%$, respectively more than control (Table 10 and Figure 6). Moreover, the results showed that the anatomical characters of fruit tissues improved with foliar potassium applications (Table 11 and Figure 7). The maximum values of studied characters were recorded with plants treated with $\mathrm{K}_{2} \mathrm{SO}_{4}$. The increments over control were, 38.8, 72.7, 24.6, 27.7, 42.8 and $28.9 \%$ for thickness of exocarp, collenchymas, parenchyma, vascular bundle, endocarp and whole pericarp, respectively. This improvement in cell size and thickness of fruits could be attributed to increase accumulation of metabolic compounds (i.e. sugars). Several investigators also reported that growth promotion of numerous crops supplied with sufficient amount of $\mathrm{K}$ fertilisers, either as foliar feeding or soil application, could be attributed to its function in activation of many enzymes correlated to leaf pigment formation, photosynthesis processes and biosynthesis of metabolic compounds involved to plant development (Amtmann et al. 2008; Kaur et al. 2007; Qua et al. 2012). Arafa et al. (2011) mentioned that potassium fertiliser significantly increased stem and pith diameter, collenchyma thickness, chlorenchymatous layer thickness, length and width of vascular bundle, as well as the thickness of phloem and xylem. Contrary, $\mathrm{KCl}$ fertiliser showed lowest value of thickness of different tissues, but the values are higher than control plants. This observation suggested that $\mathrm{KCl}$ has a higher salt content than $\mathrm{K}_{2} \mathrm{SO}_{4}$ (Kamburova \& Kirilov 2008) and accumulation of $\mathrm{Cl}$ anion inside cells induced the toxic-
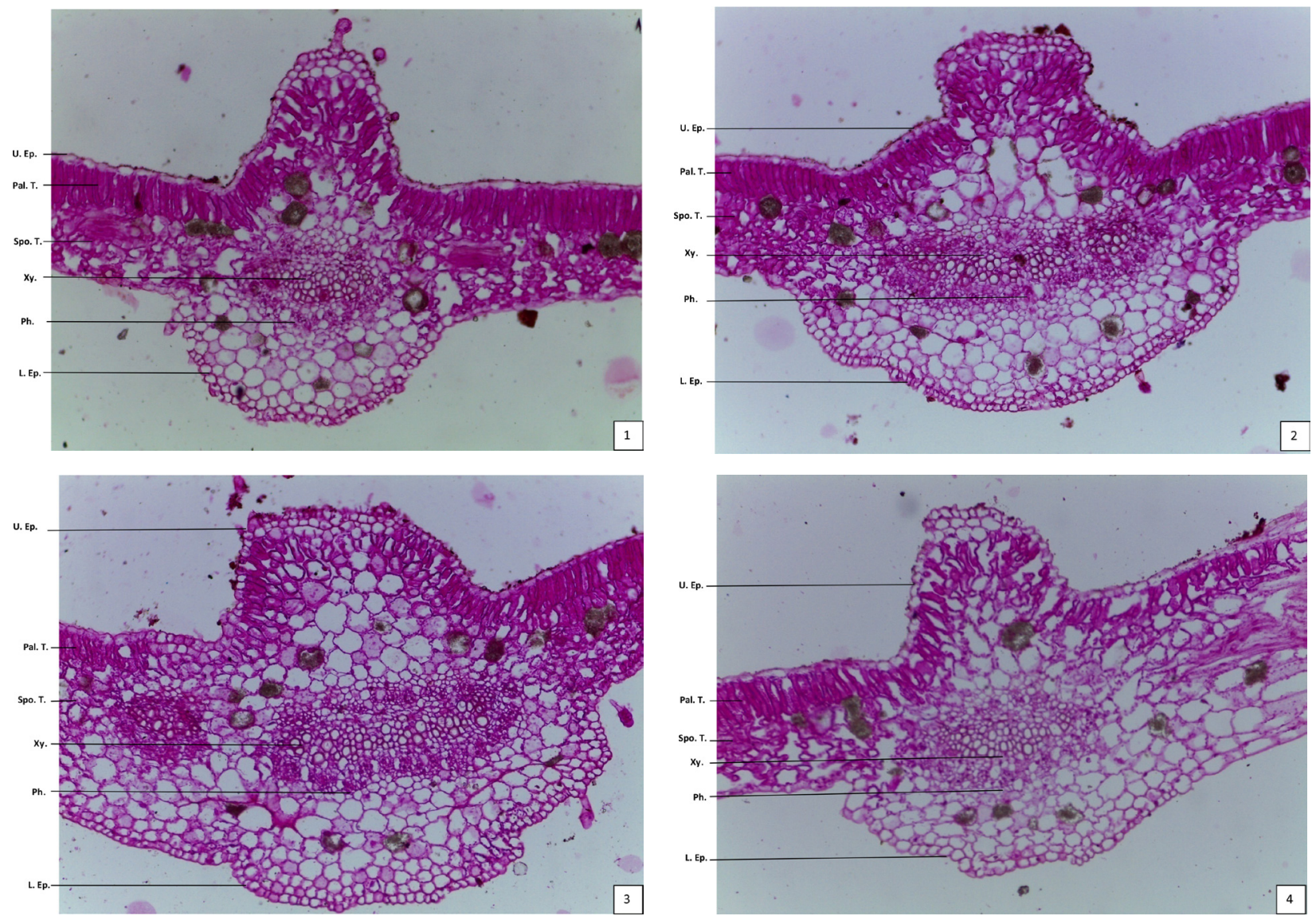

Figure 5. Transverse sections through the blade of $4^{\text {th }}$ leaf of pepper plant as affected by foliar application with (1) untreated plant (control), (2) plant treated with potassium humate, (3) plant treated with potassium sulphate and (4) plant treated with potassium chloride. (U.ep.) - Upper epidermis, (Pal.) - Palaside tissue, (Spo.) - Spongy tissue, (Xy.) - Xylem, (Ph.) - Phloem and (L. ep.) - Lower epidermis. 

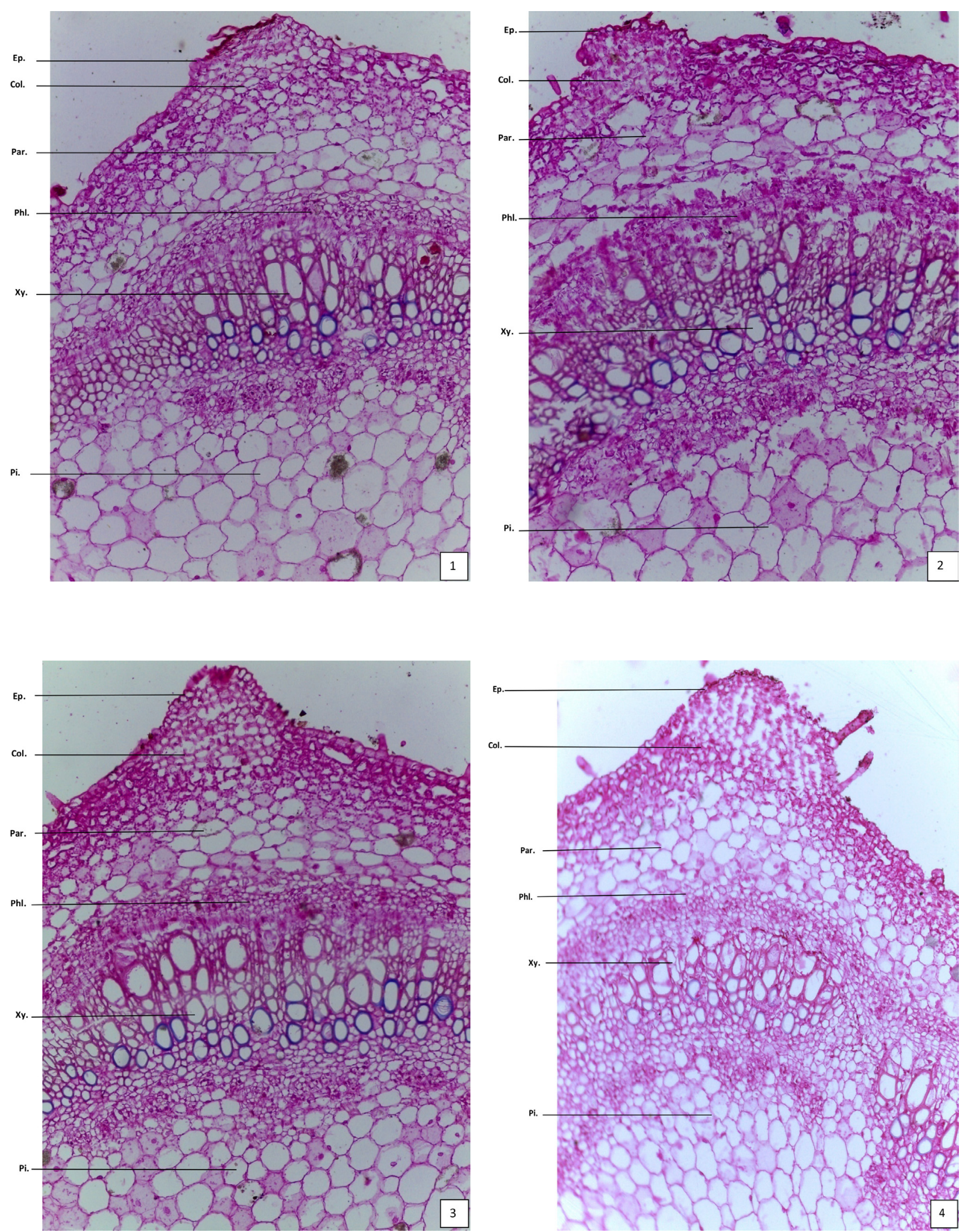

Figure 6. Transverse sections through median portion of the main stem of pepper plant at the age of 90 days as affected by foliar application with (1) untreated plant (control), (2) plant treated with potassium humate, (3) plant treated with potassium sulphate and (4) plant treated with potassium chloride. (Ep.) - Epidermis, (Col.) - Collenchayma, (Par.) - parenchyma, $(\mathrm{Ph})-.\mathrm{Phloem}$, (Xy.) - Xylem and (Pi.) - pith. 

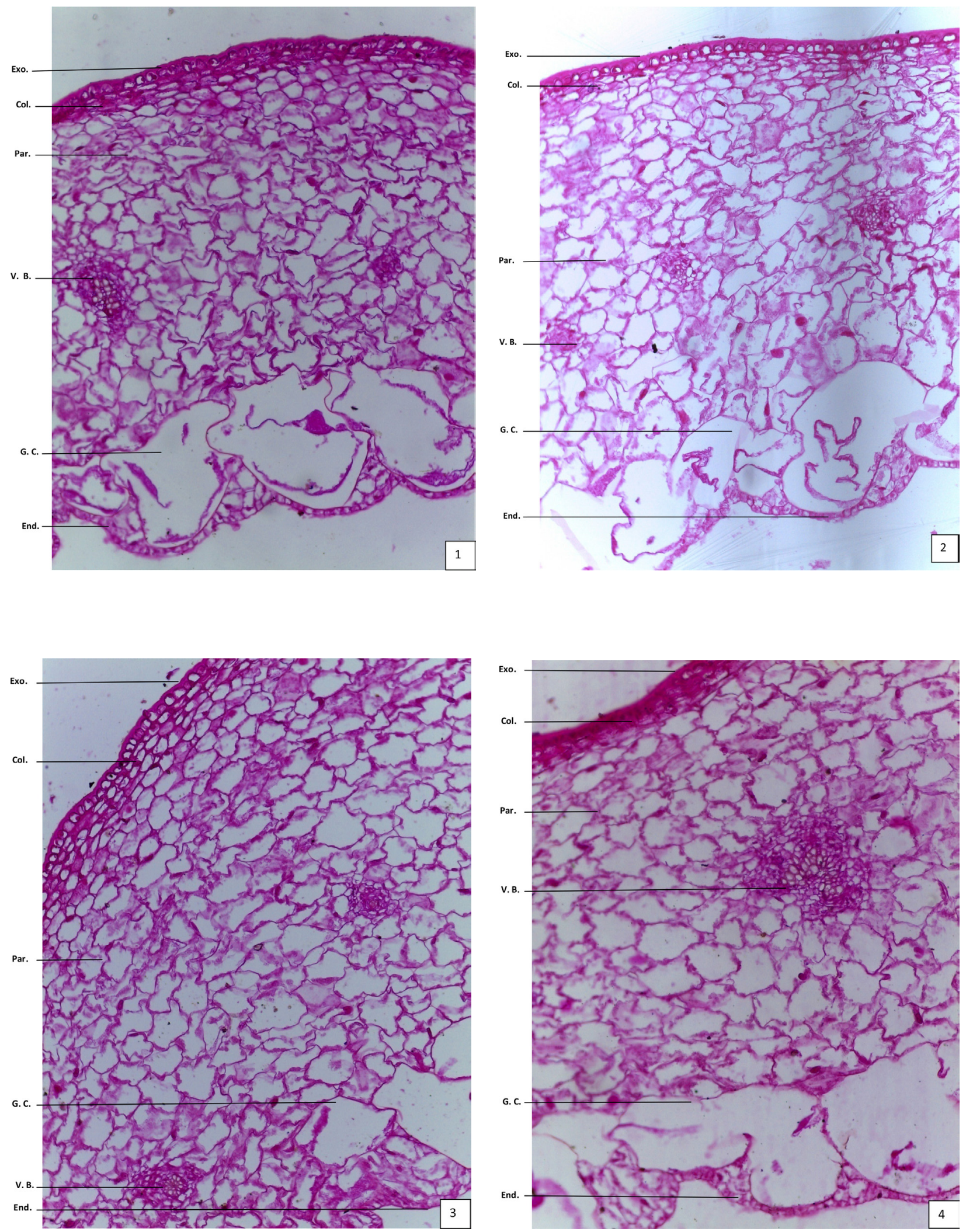

Figure 7. Transverse sections through median portion of the fruit of pepper plant at the age of 120 days as affected by foliar application with (1) untreated plant (control), (2) plant treated with potassium humate, (3) plant treated with potassium sulphate and (4) plant treated with potassium chloride. (Exo). - Exocarp, (Col.) - Collenchyma, (Par.) - Parenchyma, (V.B.) - Vascular bundle, (G.C.) - Giant cell and (End.) - Endocarp. 
ity and reduced the cell size and thickness of plant tissues. Cutter and Murphey (1978) indicated that K affected vessel wall thickness and vessel length of pepper that it may affect xylem vessel conductivity.

\section{CONCLUSIONS}

The present study indicated that supplementing foliar $\mathrm{K}$ sources during the plant growth and fruit development can improve pepper fruit quality parameters and bioactive compounds. All the foliar $\mathrm{K}$ sources, especially $\mathrm{K}_{2} \mathrm{SO}_{4}$, were effective in improving photosynthetic process, plant biomass, and total yield, total sugars, carotenoids, chlorophyll ( $a$ and $b$ ), and endogenous NPK. Morever, foliar application of $\mathrm{K}_{2} \mathrm{SO}_{4}$. Morever, foliar application of $\mathrm{K}_{2} \mathrm{SO}_{4}$ recorded the maximum promotion in all anatomical characters for leaf, stem and fruit of pepper plant. Increasing available $\mathrm{K}$ element for pepper plant by foliar fertiliser treatment could be an effective easily method that growers can be used for increasing pepper yield and quality.

\section{REFERENCES}

ABDELAZIZ, M.E. - ABDELDAYM, E.A. 2018. Cucumber growth, yield and quality of plants grown in peatmoss or sand as affected by rate of foliar applied potassium. In Bioscience Research, vol. 15, no. 3, pp. 2871-2879.

ABID, M.Z. - TIAN, S.T. - ATA-UL-KARIM, F. - WANG, Y. - LIU, R. - ZAHOOR, D. - JIANG, L. - DAI, T. 2016. Adaptation to and recovery from drought stress at vegetative stages in wheat (Triticumae stivum) cultivars. In Functional Plant Biology, vol. 43, pp. 1159-1169. https://doi. org/10.1071/fp16150

ACOSTA-MOTOS, J.R. - ORTUÑO, M.F. - BERNAL-VICENTE, A. - DIAZ-VIVANCOS, P. - SANCHEZ-BLANCO, M.J. - HERNANDEZ, J.A. 2017. Plant responses to salt stress: Adaptive mechanisms. In Agronomy, vol. 7, pp. $1-38$.

AFZAL, I. - HUSSAIN, B. - BASRA, S.M.A. - ULLAH, S.H. - SHAKEEL, Q. - KAMRAN, M. 2015. Foliar application of potassium improves fruit quality and yield of tomato plants. In Acta Scientiarum Polonorum, Hortorum Cultus, vol. 14 , no. 1 , pp. $3-13$.

AMTMANN, A. - TROUFFLARD, S. - ARMENGAUD, P. 2008. The effect of potassium nutrition on pest and disease resistance in plants. In Physiologia Plantarum, vol. 133, pp. $682-691$

AOAC, 1990. Official methods of analysis of the Association of Official Analytical Chemists, $15^{\text {th }}$ ed., Association of Official Analytical Chemists, Arlington VA, pp. 1058-1059.

AOAC, 1975. Official methods of analysis of the Association of Official Analysis Chemists, $12^{\text {th }}$ ed., Association of Official Analytical Chemists, Washington. C. 200044.
ARAFA, A.A. - FAROUK, S. - HAGER, S.M. 2011. Effect of potassium fertiliser, biostimulants and effective microorganisms as well as their interactions on potato growth, photosynthetic pigments and stem anatomy. In Journal of Plant Production, vol. 8, no. 2, pp. 1017-1035.

BAHMANYAR, M.A. - MASHAE, S.S. 2010. Influences of nitrogen and potassium top dressing on yield and yield components as well as their accumulation in rice (Oryzasativa). In African Journal of Biotechnology, vol. 9, no. 18, pp. $2648-2653$.

BOTELLA, M.A. - ARÉVALO, L. - MESTRE, T.C. - RUBIO, F. - GARCÍA-SÁNCHEZ, F. - RIVERO, R.M. MARTÍNEZ, V. 2017. Potassium fertilization enhances pepper fruit quality. In Journal of Plant Nutrition, vol. 40, no. 2, pp. $145-155$.

BROWN, J.D. - LILLILAND, O. 1964. Rapid determination of potassium and sodium in plant materials and soil extracts by flame photometer. In Proceedings of the Society for Horticultural Science, vol. 48, pp. 341-346.

CHAPAGAIN, B.P. - WIESMAN, Z. 2004. Effect of NutriVant-PeaK foliar spray on plant development, yield, and fruit quality in greenhouse tomatoes. In Scientia Horticulturae, vol. 102, pp. 177-188.

COSKUN, D. - BRITTO, D.T. - KRONZUCKER, H.J. 2014. The physiology of channel-mediated $\mathrm{K}^{+}$acquisition in roots of higher plants. In Physiologia Plantarum, vol. 151, pp. $305-312$.

CUTTER, B.C. - MURPHEY, W.K. 1978. Effects of potassium on growth and wood anatomy of a Populus hybrid. In Wood Fiber, vol. 9, pp. 282-288.

DOBROVICZKÂ, T. - PIRŠELOVÁ, B. - MÉSZÁROS, P. BLEHOVÁ, A. - LIBANTOVÁ, J. - MORAVČÍKOVÁ, J. - MATUŠÍKOVÁ, I. 2013. Effects of cadmium and arsenic ions on content of photosynthetic Pigments in the leaves of Glycine max (L.) Merrill. In Pakistan Journal of Botany, vol. 45 , no. 1 , pp. $105-110$.

FAGERIA, N.K. 2009. The use of nutrients in crop plants. Boca Raton, FL. : Taylor \& Francis Group, 448 p. DOI: 10.201/9781420075113

FARAGO, M.E. 2008. Plants and the chemical elements : Biochemistry, uptake, tolerance and toxicity. Wiley-Blackwell, 302 p. ISBN 978-3-527-61590-2

GHASEMZADEH, A. - JAAFAR, H.Z.E. 2011. Effect of $\mathrm{CO}_{2}$ enrichment on synthesis of some primary and secondary metabolites in ginger (Zingiber officinale Roscoe). In International Journal of Molecular Sciences, vol. 12, pp. $1101-1114$.

GHASEMZADEH, A. - JAAFAR, H.Z.E. - RAHMAT, A. WAHAB, P.E.M. - HALIM, M.R.A. 2010. Effect of different light intensities on total phenolics and flavonoids synthesis and anti-oxidant activities in young ginger varieties (Zingiber officinale Roscoe). In International Journal of Molecular Sciences, vol. 11, pp. 3885-3897.

GIUFFRIDA, F. - GRAZIANI, G. - FOGLIANO, V. - SCUDERI, D. - ROMANO, D. - LEONARDI. C. 2014. Effects of nutrient and $\mathrm{NaCl}$ salinity on growth, yield, quality and composition of pepper grown in soilless closed system. In Journal of Plant Nutrition, vol. 37, pp. 1455-1474.

GOLCZ, A. - KUJAWSKI, P. - MARKIEWICZ, B. 2012. Yielding of red pepper (Capsicum annuum L.) under the influence of varied potassium fertilization. In Actas Scientiarum Polonorum, Hortorum Cultus, vol. 11, no. 4, pp. 3-15.

GOLCZ, A. - KUJAWSKI, P. - ZIMOWSKA, H. 2004. Effect of potassium fertilizer type on the content of nutritive components in the leaves and fruits of hot pepper (Capsicum anuum L.). In Roczniki Akademii Rolniczej Poznaniu - CCCLVI, vol. 37, pp. 75-80. 
HANCOCK, R.D. - VIOLA, R. 2005. Biosynthesis and catabolism of L-ascorbic acid in plants. In Critical Reviews in Plant Sciences, vol. 24, pp. 167-188.

IBRAHIM, M.H. - JAAFAR, H.Z. - RAHMAT, A. - RAHMAN, Z.A. 2011. Effects of nitrogen fertilization on synthesis of primary and secondary metabolites in three varieties of Kacip Fatimah (Labisia pumila Blume). In International Journal of Molecular Sciences, vol. 12, pp. 5238-5254.

IBRAHIM, M.H. - JAAFAR, H.Z.E. - KARIMI, E. - GHASEMZADEH, A. 2012. Primary, secondary metabolites, photosynthetic capacity and antioxidant activity of the malaysian herb Kacip Fatimah (Labisia pumila Benth) exposed to potassium fertilization under greenhouse conditions. In International Journal of Molecular Sciences, vol. 13, pp. $15321-15342$

INTHICHACK, P. - NISHIMURA, Y. - FUKUMOTO, Y. 2012. Effect of potassium sources and rates on plant growth, mineral absorption, and the incidence of tip burn in cabbage, celery, and lettuce. In Horticulture Environment and Biotechnology, vol. 53, pp. 135-142.

KAMBUROVA, K. - KIRILOV, P.L. 2008. Calculating the salt index of $\mathrm{pK}$ and NPK liquid fertilizers from potassium phosphates. In Journal of Chemical Technology and Metallurgy, vol. 43, pp. 227-230.

KAUR, K. - GUPT, A.A.K. - KAUR, N. 2007. Effect of water deficit on carbohydrate status and enzymes of carbohydrate metabolism in seedlings of wheat cultivars. In Journal of Biochemistry and Biophysics, vol. 44, pp. 223-230.

LESTER, G.E. - GRUSAK, M.A. 1999. Postharvest application of calcium and magnesium to honey- dew and netted muskmelons: Effects on tissue ion concentrations, quality and senescence. In Journal of the American Society for Horticultural Science, vol. 124, pp. 545-552.

LESTER, G.E. - JIFON, J.L. - MAKUS, D.J. 2006. Supplemental foliar potassium applications with or without a surfactant can enhance netted muskmelon quality. In Hort Science, vol. 41 , pp. $741-744$.

LESTER, G.E. - JIFON, J.L. - ROGERS, G. 2005. Supplemental foliar potassium applications during muskmelon $(\mathrm{Cu}$ cumis melo L.) fruit development can improve fruit quality, ascorbic acid and beta-carotene contents. In Journal of the American Society for Horticultural Science, vol. 130, pp. 649-653.

LESTER, G.E. - JIFON, J.L. - MAKUS, D.J. 2010. Impact of potassium nutrition on postharvest fruit quality: Melon (Cucumis melo L) case study. In Plant Soil, vol. 335, pp. $117-131$

LI, W. - HE, P. - JIN, J. 2009. Potassium influenced phenylalanine ammonia-lyase, peroxidases and polyphenol oxidases in Fusarium graminearum infected maize (Zea mays L.). In Proceedings of the International Plant Nutrition Colloquium XVI, Davis, CA, USA.

LICHTENTHALER, H.K. - WELLBURN, A.R. 1983. Determinations of total carotenoids and chlorophylls $a$ and $b$ of leaf extracts in different solvents. In Biochemical Society Transactions, vol. 11, pp. 591-592.

LIN, D. - HUANG, D. - WANG, S. 2004. Effects of potassium levels on fruit quality of musk melon in soilless medium culture. In Scientia Horticulturae, vol. 102, no. 1, pp. 53-60.

MAHMOUD, A.W.M. - ABDELAZIZ, S.M. - EL-MOGY, M.M. - ABDELDAYM, E.A. 2019. Effect of foliar ZnO and $\mathrm{FeO}$ nanoparticles application on growth and nutritional quality of red radish and assessment of their accumulation on human health. In Agriculture (Pol'nohospodárstvo), vol. 65, no. 1, pp. 16-29. DOI: 10.2478/agri-2019-0002

MARSCHNER, P. - MARSCHNER, S. 2012. Mineral Nutrition of Higher Plants. 3rd ed. London, UK : Academic Press, pp. $178-189$.
NASSAR, M.A. - EL-SAHHAR, K.F. 1998. Botanical Preparations and Microscopy (Microtechnique). Dokki, Giza, Egypt : Academic Bookshop, 219 p.

NORHAIZA, M. - MAZIAH, M. - HAKIMAN, M. 2009. Antioxidative properties of leaf extracts of popular Malaysian herb, Labisiapumila. In Journal of Medicinal Plants Research, vol. 3, pp. 217-223.

O'TOOLE, J.C. - TREHARNE, K. - TURNIPSEED, M. CROOKSTON, K. - OZBUN, J. 1980. Effect of potassium nutrition on leaf anatomy and net photosynthesis of Phaseolus vulgaris L. In The New Phytologist, vol. 84, pp. $623-630$.

PENG, J. - LIU, J. - ZHANG, L. - LUO, J. - DONG, H. - MA, Y. - ZHAO, X. - CHEN, B. -SUI, N. - ZHOU, Z. - MENG, Y. 2016. Effects of soil salinity on sucrose metabolism in cotton leaves. In Plos ONE, vol. 11, no. 5: e0156241.

PERVEZ, H. - MAKHDUM, M.I. - ASHRAF, M. - SHABAB, U.D. 2006. Influence of potassium nutrition on leaf area index in cotton (Gossypium hirsutum L.) under an arid environment. In Pakistan Journal of Botany, vol. 38, no. 4, pp. $1085-1092$.

PIPER, C.S. 1947. Soil and Plant Analysis. Adelaide, UK : The University of Adelaide, $368 \mathrm{p}$.

PREGL, F. 1945. Quantitative-organic Micro-analysis. 4th ed., London : J. and A. Churchill Ltd.

QUA, C. - LIUA, C. - GONGA, X. - LI, C. - HONG, M. WANG, L. - HONG, F. 2012. Impairment of maize seedling photosynthesis caused by a combination of potassium deficiency and salt stress. In Environmental and Experimental Botany, vol. 75, pp. 134-141.

SALAMA, S. - TRIVEDI, S. - BUSHEVA, M. - ARATA, A.A. - GRAB, G. - ERDEI, L. 1994. Effects of NaCl salinity on growth, cation accumulation, chloroplast structure and function in wheat cultivars differing in salt tolerance. In Journal of Plant Physiology, vol. 144, pp. 241-247.

SHEHATA, S.A. - EL-MOGY, M.M. - MOHAMED, H.F.Y. 2019. Postharvest quality and nutrient contents of long sweet pepper enhanced by supplementary potassium foliar application. In International Journal of Vegetable Science, vol. 25 , no. 2 , pp. 196-209.

SHUI, Y.C. - FENG, X. - YAN, W. 2009. Advances in the study of flavonoids in Gingko biloba leaves. In Journal of Medicinal Plants Research, vol. 3, pp. 1248-1252.

SUN, J. - LI, C.H. - SUN, H.Y. - CAO, M.J. - WANG, X.G. 2011. The effect of low potassium stress on growth and development of different soybean genotypes. In Chinese Journal of Soil Science, vol. 42, pp. 431-434.

SWAIN, T. - HILLIS, W.E. 1959. The phenolic constituents of Prunusdomestica $\mathrm{L}$. The quantitative analysis of phenolic constituents. In The Journal of the Science of Food and Agriculture, vol. 10 , pp. $63-68$.

TRIPURA, P. - KUMAR, S. - VERMA, R. 2017. Effect of potassium humate and bio-inoculants on nutrient content, uptake and quality of cowpea (Vignaun guiculata (L.) Walp. In International Journal of Current Microbiology and Applied Sciences, vol. 6, no. 2, pp. 1735-1741.

ZAHOOR, R. - DONG, H. - ABID, M. - ZHAO, W. - WANG, Y. - ZHOU, Z. 2017. Potassium fertilizer improves drought stress alleviation potential in cotton by enhancing photosynthesis and carbohydrate metabolism. In Environmental and Experimental Botany, vol. 137, pp. 73-83.

ZHAO, D. - OOSTERHUIS, D.M. - BEDNARZ, C.W. 2001. Influence of potassium deficiency on photosynthesis, chlorophyll content, and chloroplast ultrastructure of cotton plants. In Photosynthetica, vol. 39, pp. 103-109.

Received: October 20, 2019

Accepted: June 6, 2019 